\title{
Chapter 9 \\ Smart Harvest Operations and Timber \\ Processing for Improved Forest Management
}

\author{
G. Picchi, J. Sandak, S. Grigolato, P. Panzacchi, and R. Tognetti
}

\begin{abstract}
Climate-smart forestry can be regarded as the evolution of traditional silviculture. As such, it must rely on smart harvesting equipment and techniques for a reliable and effective application. The introduction of sensors and digital information technologies in forest inventories, operation planning, and work execution enables the achievement of the desired results and provides a range of additional opportunities and data. The latter may help to better understand the results of management options on forest health, timber quality, and many other applications. The introduction of intelligent forest machines may multiply the beneficial effect of digital data gathered for forest monitoring and management, resulting in forest harvesting operations being more sustainable in terms of costs and environment. The interaction can be pushed even further by including the timber processing industry, which assesses physical and chemical characteristics of wood with sensors to optimize the transformation process. With the support of an item-
\end{abstract}

\footnotetext{
G. Picchi $(\bowtie)$

Institute of Bioeconomy of the National Research Council (CNR-IBE),

Sesto Fiorentino, Italy

e-mail: gianni.picchi@cnr.it

J. Sandak

InnoRenew CoE, Izola, Slovenia

e-mail: jakub.sandak@innorenew.eu

S. Grigolato

Department of Land, Environment, Agriculture and Forestry, Università degli Studi di

Padova, Legnaro, PD, Italy

e-mail: stefano.grigolato@unipd.it

P. Panzacchi

Department of Biosciences and Territory, Università degli Studi del Molise, Pesche, Italy

Faculty of Science and Technology, Free University of Bolzano-Bozen, Bolzano, Italy

R. Tognetti

Dipartimento di Agricoltura, Ambiente e Alimenti, Università degli Studi del Molise,

Campobasso, Italy

e-mail: tognetti@unimol.it
} 
level traceability system, the same data could provide a formidable contribution to CSF. The "memory" of wood could support scientists to understand the response of trees to climate-induced stresses and to design accordingly an adaptive silviculture, contributing to forest resilience in the face of future changes due to human-induced climate alteration.

\section{Acronyms}

$\begin{array}{ll}\text { AHP } & \text { Analytic hierarchy process } \\ \text { CHM } & \text { Canopy height model } \\ \text { CSF } & \text { Climate-smart forestry } \\ \text { CT } & \text { Computed tomography } \\ \text { DBH } & \text { Diameter at breast height } \\ \text { DSM } & \text { Digital surface model } \\ \text { DTM } & \text { Digital terrain model } \\ \text { FI } & \text { Forest inventory } \\ \text { GHG } & \text { Greenhouse gases } \\ \text { GNSS } & \text { Global navigation satellite system } \\ \text { HF } & \text { High frequency } \\ \text { LF } & \text { Low frequency } \\ \text { LiDAR } & \text { Laser imaging detection and ranging } \\ \text { MOE } & \text { Modulus of elasticity } \\ \text { MOEd } & \text { Dynamic modulus of elasticity } \\ \text { NIR } & \text { Near-infrared } \\ \text { OGC } & \text { Open Geospatial Consortium } \\ \text { PF } & \text { Precision forestry } \\ \text { QR } & \text { Quick response (code) } \\ \text { RFID } & \text { Radio frequency identification } \\ \text { RGB } & \text { Red-green-blue, visible light } \\ \text { SFO } & \text { Sustainable forest operations } \\ \text { StandForD } & \text { Standard for Forest Machine Data and Communication } \\ \text { SWE } & \text { Sensor web enablement (initiative) } \\ \text { TLS } & \text { Terrestrial laser scanning } \\ \text { UAV } & \text { Unmanned aerial vehicle } \\ \text { UHF } & \text { Ultrahigh frequency } \\ \text { UPC } & \text { Universal product code } \\ \text { UV } & \text { Ultraviolet } \\ \text { VF } & \text { Virtual forest } \\ & \end{array}$




\subsection{Climate-Smart Forestry and Forest Operations}

Climate change is altering the ecological equilibrium of our planet. Forests are among the most affected ecosystems due to the increasing damages caused directly or indirectly by rising temperatures, such as droughts, wildfires, and pest attacks. On the other hand, in the Land Use, Land Use Change and Forestry sector (LULUCF), forests are considered a key tool in tackling greenhouse gases (GHG) concentration in the atmosphere. In this regard, there is an open debate concerning the most appropriate use and management of forests. Some researchers consider a priority the carbon sequestration capacity of forest ecosystems, suggesting a focus on the accumulation of carbon in forest biomass and soils. This would be achieved with a specific management approach and reduction of timber harvests (Holtsmark 2012). The concern over timber extraction is not only related to illegal logging but also regarding the production of forest biomass for energy (Searchinger et al. 2018). Nevertheless, while illegal logging and deforestation are unanimously regarded as a threat, several authors consider that under appropriate management and regulations, timber and biomass extraction may contribute positively to an overall net carbon control (Kauppi et al. 2018; Favero et al. 2020), e.g., through substitution of fossil fuel-based products.

In this frame, the productive functions of forests are essential to guarantee an effective contribution to GHG mitigation. In fact, they provide renewable materials and fuels (substituting fossil-derived alternatives), food, as well as other non-wood forest products, whose importance may sometimes offset the role of woody materials (Sheppard et al. 2020). The production of goods with direct economic value is essential to support local communities and rural development. This in turn ensures forest management and preservation is economically and technically feasible. For instance, by allowing the presence of local inhabitants, which represent both the workforce and the main users/monitors of forests.

A possible answer to this complex scenario is provided by climate-smart forestry (CSF) (Yousefpour et al. 2018). This is a comprehensive approach, addressing the goals of Sustainable Forest Management (SFM) and the threat of climate change by enabling both forests and society to transform, adapt to, and mitigate climateinduced changes (Bowditch et al. 2020).

The previous and following chapters of this book describe in detail the concept of CSF as well as the solutions envisaged for its application and the tools used for forest monitoring. The present chapter focuses on the contribution that forest operations and, in a broader vision, the whole timber supply chain can provide to CSF application. This contribution can be summarized by two main roles:

- Active forest management

- Production of data at plot and tree level

Even if they stem from the same activities, these two roles can be easily differentiated when considered as part of CSF. In fact, the former is the application in practice of the management strategies, acting "passively" while implementing 
the guidelines and instructions elaborated by CSF models. The latter, instead, is an active contribution to the development of such models. In fact, the data produced and stored all along the timber supply chain can be used to better understand forest dynamics and improve the very models previously mentioned, closing the loop.

Active forest management is based on the use of specific technologies and techniques. These can be combined to achieve both processes efficiency, social benefits, and minimal environmental impact, implementing the concept of sustainable forest operations (SFO) as introduced by Marchi et al. (2018). SFO deployed in the frame of an adaptive silviculture is a crucial tool to enhance the resilience of forests and to achieve the following goals:

- Increase the sustainability of timber and forest biomass production

- Directly or indirectly enhance or maintain the production of non-wood forest products and indirect services, such as water supply and carbon sequestration

- Implementation of sustainable and smart silviculture practices, such as tree species change, age mixing, density reduction, or salvaging operations

In order to secure a fast and effective implementation of SFO guidelines, sensing and digital technologies are necessary to plan, manage, and execute forest works, creating a link between SFO and precision forestry (PF). The latter can be defined as the application in forestry of geospatial information and remotely sensed data for planning silvicultural operations at the level of stand, sub-stand, or even individual trees (Holopainen et al. 2014). For instance, planning may identify broad restricted areas, as may be the case of riparian vegetation surrounding water bodies enclosed in the forest (e.g., ponds or creeks), but with individual-tree detail level, it can address the protection of individual trees (e.g., trees hosting nests of protected birds' species) as well as meet the precise requirement of nature conservation instances.

Production of data at plot and tree level is one of the distinctive requirements of $\mathrm{CSF}$, which relies on the availability and elaboration of data (including the territorial scale). As described in the chapters of this book, this is essential for understanding the dynamics of forest growth and health and its responses to climate change and to draw models that support management hypotheses. Data is provided by a number of sources, ranging from satellite images to sessile sensors fixed on trees, varying greatly in territorial and time scale. Forest equipment is already an additional source of data, but the potential of machines as carriers of sensors for forest monitoring is still largely unexpressed. Furthermore, the whole timber supply chain, including the highly detailed sensors deployed by the timber transformation industry (e.g., sawmills), provides extremely valuable and accurate data regarding wood development and characteristics. This data could narrate the "memory of wood," relating the stresses and growing conditions experienced in the last decades (or centuries) by an enormous dataset of trees. For this purpose, an effective tracing system from stump to mill is necessary as well as the capacity to store and manage properly a high volume of data. 


\subsection{Timber Supply Chains and CSF: The Stat of the Art}

This section details the practical application of PF in planning and management of forest harvesting. It describes the present sources of data and their commercial application for fleet control and for estimate of timber and biomass yield. Additionally, it discusses the developments expected in the near future and the main research lines currently known. All the information or data infrastructure is also considered from the point of view of CSF, and the potential synergies between commercial operations and forest monitoring activities are highlighted.

\subsubsection{From Forest Inventories to the Virtual Forest}

At present, forest inventories (FI) are the most common application of precision forestry. For this purpose, visible (red/green/blue, RGB) or hyperspectral images are the main data source, collected from airborne sensors installed on different carriers, such as satellites (long distance), airplanes (medium distance), and unmanned aerial vehicles (UAVs) for short distances (White et al. 2016). Forest inventories are generally integrated with thematic maps, such as soil layers, forest treatments, tree species composition, and any relevant information reported. A detailed forest inventory plays a key role in the management of the forest as well as in its economic valorization (which may aim at producing an income for the owner or simply to cover the costs of the necessary management operations, depending on the function assigned to the forest stand). For this purpose, it includes not only quantitative values, such as timber volume, age distribution, and structure of the forest stand, but also qualitative figures, such as health and fertility of the stands composing the forest.

A further technology with great potential and consolidated application in forest sector is the laser imaging detection and ranging (LiDAR), which has proven particularly effective in large-scale inventories, integrating data elaborated from RGB sensors (Matasci et al. 2018) and multispectral sensors (Puliti et al. 2020). Compared to the latter source of data, LiDAR provides a more reliable $3 \mathrm{D}$ information (Noordermeer et al. 2019) and allows a better estimate of the growing stock and the relative value of the harvestable roundwood (Peuhkurinen 2011). The assessment of the quantity and market value of growing stock can be further enhanced thanks to the application of terrestrial laser scanner (TLS). This can integrate both traditional inventories and aerial surveys, returning a detailed inventory including number of trees, shape and taper of stems, crow insertion, and other parameters not detectable with aerial, above-crown sensing (Mengesha et al. 2015). For instance, by integrating RGB images taken from UAVs with TLS scanning, Pichler et al. (2017) increased the effective volume estimation of the trees in the stand from below $80 \%$ for the aerial data to over $94 \%$ of the combined dataset. This proves the potential of merging data originated from different sensors and integrated with 
other digital information sources such as topographic or thematic maps (e.g., pedological layers) and traditional forest inventories. Such multisensor data fusion leads to the generation of a digital model of the studied object (Mitchell 2012), in this case the forest. This can be defined as the "virtual forest" (Rossmann et al. 2009), which gathers accurate, consistent, and readily available information regarding the real forest. This information is used to better plan and manage commercial forest operations. Some examples may be given by forest road and skid trail planning and georeferencing (Đuka et al. 2017). The virtual forest and the related database are both generated for and paid by forest management and harvest operations. Yet, from the point of view of CSF, they can be regarded as an excellent and massive data collection infrastructure. In fact, the availability of such an integrated network of sensors can provide stand-specific information extremely useful to monitor the forest physiology and health parameters (see also Chap. 10 of this book: Tognetti et al. 2021).

\subsubsection{Multipurpose Forest Operation Planning}

Cost optimization remains the foremost aim (and driver) of forest operation planning. Yet, forest operation plans are also the main tool used to balance forest growth and extraction of woody products, to minimize impact on soil and water resources and to guarantee the conservation of biodiversity.

Over time, the common timber-oriented planning approach has introduced an increasing number of targets, such as minimizing the damages to the remaining standing trees (still a timber-oriented goal). The development of a multi-target forest operation plan is a complex task, which requires more data regarding the forest and a higher capacity to elaborate and interconnect this information. For this purpose, the digital database of the virtual forest (VF) is the perfect source of data, which is not only related to standing trees but also to other descriptors of the forest. For instance, LiDAR data is also used to detail the terrain features through the digital surface model (DSM) and the digital terrain model (DTM). These are used to derive the canopy high model (CHM) but provide also relevant information regarding terrain and soil characteristics such as roughness, slope and, with the integration of sampling plots, bearing capacity (Pirotti et al. 2012).

The high-resolution 3D data of the VF combined with multi-spectrum satellite data collected in frequent time series is a key element to optimize planning of forest operations. It allows to minimize the transit for forest machines and to set predefined skidding trails (Sterenczak and Moskalik 2015) and cable layout (Bont and Heinimann 2012) that increase efficiency of the operations, reducing costs per cubic meter of timber extracted. As an example, Fig. 9.1 shows a GIS analysis to evaluate alternative forwarder paths in an Alpine environment by considering variables I) slope and roughness of the terrain and II) the density of the forest stand. The variables were determined from LiDAR data: in particular, the digital terrain model (DTM) (a), the canopy height model (CHM) (b), the terrain roughness (c), and the cost surface normalizing and summarizing the previous data $(\mathrm{d})$. 

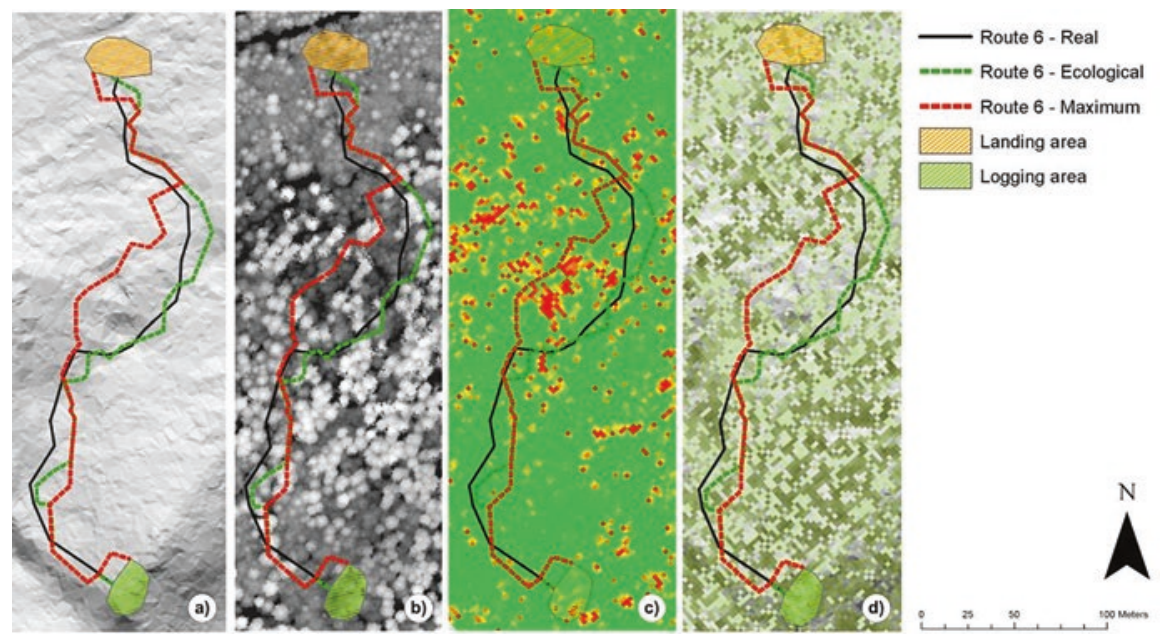

Fig. 9.1 Example of timber hauling operation planning based on digital data. (Credits: Marco Pellegrin, Project NewFor)

Based on the mobility parameters of a medium-size forwarder, two different paths were generated: the ecological path (maximum uphill slope $30 \%$ and maximum downhill slope $43 \%$ ) and the maximum path (maximum uphill slope $35 \%$ and maximum downhill slope $67 \%$ and a maximum lateral inclination of $4 \%$ ), a path considering the maximum mobility limits of the machine. In both cases, the maximum lateral inclination was supposed to be $4 \%$. The generated paths were then compared with the real paths of the machine driven by an expert operator.

Thanks to the high detail of the data, plans can get to a tree-level resolution and evaluate the interaction among trees at stand level and the trees' group dynamics (Pirotti et al. 2012; Lindberg and Holmgren 2017). This creates a link with the climate-smart silvicultural prescriptions described in Chap. 8 of this book (Pach et al. 2021) and strengthens the connection that may (and should) exist between the timber supply chains and CSF aims. Examples of this interaction can be provided by forest operation plans tailored to include the priority of habitats conservation, to tackle the spread of forest pests, and to consider the hydrological effect of logging extraction (Blagojević et al. 2019; Görgens et al. 2020). The reduction of soil damage due to forest operation can take advantage from the use of high-resolution data as reported by (Niemi et al. 2017; Salmivaara et al. 2018). Minimizing soil damage is one of the most important targets for the sustainability of forest operation to preserve soil fertility and forest regeneration and to reduce the rate of soil erosion (Cambi et al. 2015; Venanzi et al. 2019), for instance, by developing detailed wetindex and terrain mobility maps (Murphy et al. 2008; Mattila and Tokola 2019). Additionally, in the last two decades, water quality preservation has been introduced as a relevant factor in the planning of forest operations (Keleş and Baskent 2011). This is particularly relevant in mountain areas where the need to maintain wood production while preserving water quality coexists, maximizing the ecosystem services provided by the forest (Ovando and Speich 2020). 
The higher complexity of multi-target planning calls for more powerful systems of data interpretation and modeling of forest dynamics. In fact, the more factors and goals are included, the higher will be the effort to develop decision tools. Analytic hierarchy process (AHP) techniques, as well as machine learning fuzzy algorithms, are increasingly deployed for such elaborations. The evaluation of the effects of forest operations in the forest environment can be even more complex when climate change effect is considered (Keenan 2015) with the related nonlinear alterations. On a world scale, climate change is influencing in different ways the operating methods connected to forest harvesting and wood transportation, as well as in the choice of silvicultural addresses and landscape conservation. Consequently, the forest management planning, which includes also the planning of forest operations, needs to be supported by more complex approaches with the introduction of nonlinear approaches and heuristic techniques (Bettinger and Boston 2017). The challenge is to accomplish complex planning, addressing all the risks faced by the forest and all the benefits provided by the same forests such as soil protection, carbon storage, biodiversity, water supply, and non-wood forest products (Matthies et al. 2019).

\subsubsection{Sensors on Forest Machines}

The appropriate implementation of the forest operation plans based on the FI (or the $\mathrm{VF}$ ) requires logging machinery or forest teams equipped with geopositioning sensors (at least) and an appropriate interface with the FI (Holopainen et al. 2014). This is even more important when there is an upgrade to the virtual forest and its larger content of digital information. Most modern machines, such as harvesters and forwarders, can already benefit from a digital FI, for instance, with a better organization of harvesting of marked trees or forwarding piled logs along predefined paths. This is possible thanks to the presence onboard of global navigation satellite system (GNSS) receivers, which provide sufficient accuracy on flat terrain, particularly on areas with limited vegetation cover, such as clear-cuts (Valbuena et al. 2012). Digital FIs at present are generally deployed to guide machines through optimal paths to follow. These are elaborated according to predefined criteria, such as minimum cost, minimum impact on soil or standing trees, or a compromise among these (Piragnolo et al. 2019). In optimal cases, where geopositioning is highly reliable and accurate, this application can be stretched to the level of a single tree to cut, implementing a virtual tree marking performed directly on the digital inventory.

This information can be further refined with the information of the exact position of the processing head or the logs grapple (boom's tip) with respect to the machine, leading in optimal conditions to a sub-metric precision in recording the position of the standing tree or the pile of logs (Lindroos et al. 2015). These machines can also feed the virtual forest with additional data collected by the onboard sensors. At present, the parameters measured are the diameters and length of the logs produced by 
the harvester: values needed to calculate the felled and processed volume (Eriksson and Lindroos 2014). These are generally used for invoicing timber produced and delivered but can also provide a detailed insight of the quantity of roundwood produced in the harvested plot (Rossit et al. 2019) and draw a balance between net annual increment and harvesting of a given forested area. Furthermore, by segregating the assortments, at least in main classes (e.g., pulp-wood vs. industrial timber), it is possible to estimate several characteristics of the harvested trees (Lu et al. 2018) and, possibly in the near future, even to develop forest yield maps (Olivera and Visser 2016).

An additional sensor, which is increasingly installed on forest machines, is the timber crane weighing load cell. It quantifies the exact masses of timber and biomass extracted by forest operations (Laurila and Lauhanen 2012). Currently, this information is used to better plan and link the different operations of the biofuel supply chain (extraction, drying, comminution and transport). It can also contribute to drawing a more precise balance between forest growth and woody products extraction (Fig. 9.2).

Finally, among the last sensors installed in forest machinery, we can report the deployment of cameras used for the automatic detection of stem damage on the trees left in the stand during harvesting. The elaboration of digital pictures, by means of logistic regression models in image processing, allows the operators to identify the damaged (debarked) trees, counting their number and ranking the level of damage (Palander et al. 2019). The system was designed to estimate timber value losses over time and the forest areas potentially susceptible to bark diseases due to damage intensity. A different elaboration of the same dataset of images could return

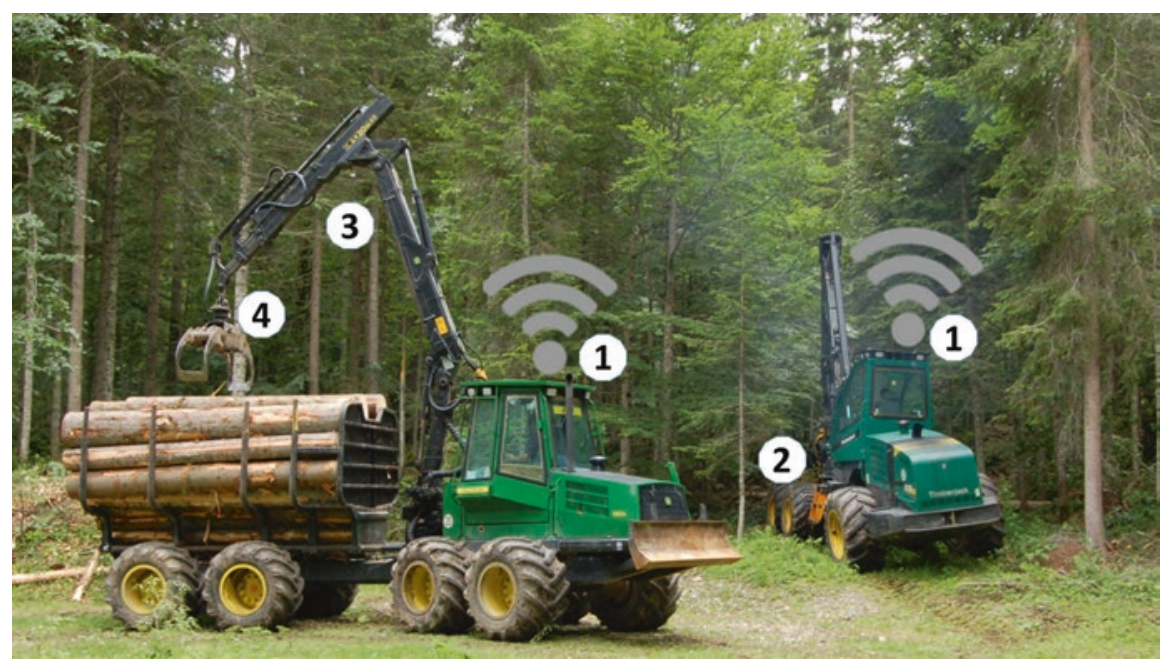

Fig. 9.2 Modern forest machines feature as a standard georeferencing sensor and wireless data transmission system (1) and encoders (in case of processor heads -2). Additionally, accurate crane positioning systems (3) and grapple load cells (4) are increasingly used 
additional services, for instance, for monitoring phenology, composition, tree cover, and biodiversity of the forest plots, where the machines transit, integrating with remote-sensing data products (see Chap. 11 of this book: Torresan et al. 2021) (Table 9.1).

Clearly, as already discussed, the maximum potential of the data provided by forest machines relies on the possibility to integrate it with other data sources, returning highly detailed estimates of stand characteristics (Barth and Holmgren 2013). Under this perspective, the potential of forest machines, as a carrier of sensors, and its capacity to interact with the virtual forest are still largely unexploited and can provide important benefits both to the efficiency of the supply chain and forest monitoring.

\subsection{Marking and Tracking Systems in Forestry}

Following the example of precision agriculture and precision farming (Mavridou et al. 2019), the evolution of onboard sensors and communication systems in forest machines has gradually made it possible to measure valuable parameters for each

Table 9.1 Main sensors currently installed on forest machines relevant for precision forestry (current) and CSF (potential) applications

\begin{tabular}{l|l|l|l|l}
\hline Sensor & Data provided & Current use & CSF contribution & $\begin{array}{l}\text { Diffusion on } \\
\text { machines }\end{array}$ \\
\hline GNSS & $\begin{array}{l}\text { Position of } \\
\text { machine }\end{array}$ & $\begin{array}{l}\text { Guiding through } \\
\text { paths predefined for } \\
\text { minimizing costs } \\
\text { and/or environmental } \\
\text { impact }\end{array}$ & $\begin{array}{l}\text { Georeferencing other } \\
\text { machine-sourced data } \\
\text { to relate it to the } \\
\text { appropriate plot or } \\
\text { forest section }\end{array}$ & $\begin{array}{l}\text { Standard in most } \\
\text { modern machines }\end{array}$ \\
\hline $\begin{array}{l}\text { Sensors of } \\
\text { prane } \\
\text { position }\end{array}$ & $\begin{array}{l}\text { Position of } \\
\text { machine }\end{array}$ & $\begin{array}{l}\text { Sub-metric (tree } \\
\text { level) positioning }\end{array}$ & $\begin{array}{l}\text { Metric precision } \\
\text { relating timber } \\
\text { properties provided by } \\
\text { onboard sensors (e.g., } \\
\text { felled volume) }\end{array}$ & $\begin{array}{l}\text { Installed in most } \\
\text { recent machines } \\
\text { but not yet } \\
\text { designed to store } \\
\text { position data }\end{array}$ \\
\hline $\begin{array}{l}\text { Encoders } \\
\text { on } \\
\text { processor } \\
\text { head }\end{array}$ & $\begin{array}{l}\text { Diameters and } \\
\text { length of logs } \\
(->\text { volume })\end{array}$ & $\begin{array}{l}\text { Volume of timber } \\
\text { produced } \\
\text { Assortments } \\
\text { identification } \\
\text { Invoicing }\end{array}$ & $\begin{array}{l}\text { Balance between } \\
\text { forest growth and } \\
\text { woody products } \\
\text { extracted } \\
\text { Main physical } \\
\text { characteristics of } \\
\text { processed stems and } \\
\text { proportion of } \\
\text { assortments } \\
\text { produced }\end{array}$ & $\begin{array}{l}\text { Standard in most } \\
\text { modern machines } \\
\text { (requires } \\
\text { routinely } \\
\text { calibration) }\end{array}$ \\
\hline $\begin{array}{l}\text { Grapple } \\
\text { scale }\end{array}$ & Handled mass & $\begin{array}{l}\text { Estimate of green } \\
\text { weight of timber and } \\
\text { biomass extracted }\end{array}$ & $\begin{array}{l}\text { More precise estimate } \\
\text { of balance between } \\
\text { forest growth and } \\
\text { woody products } \\
\text { extracted }\end{array}$ & $\begin{array}{l}\text { Available as } \\
\text { optional, present } \\
\text { in limited } \\
\text { number of } \\
\text { machines }\end{array}$ \\
\hline
\end{tabular}


produced item, such as logs and wood chips. This has promoted the development of technologies capable of automatically linking, such information to individual timber products, relating each item to its dimensions (returning volume and assortment) and to the position of the machine during the operations. Forest companies are increasingly interested in these systems, since an effective marking (tagging) system of timber products provides both track and trace services, which may significantly reduce the costs of timber production and management:

- The tracking service allows companies involved in the timber supply chain to locate their products at any moment through predefined checkpoints. It not only facilitates invoicing upon delivery of roundwood to end users but also simplifies the management of inventories.

- The tracing service allows companies, and potentially any stakeholder, to know where and when a product had been through the supply chain. It is worth pointing out that the tracing service (traceability) has the capacity to retrieve historical tracking data and appropriately save and store.

In addition to the direct economic savings, the availability of technologies for tree marking and timber product traceability would be a powerful tool for sustainable forest management disclosing or enhancing the following services:

- Certification of timber products and contrast of illegal logging in support to established certification schemes (e.g., PEFC and FSC).

- Allow to plan and execute highly precise forest works according to the guidelines of smart silviculture (described in Chap. 8 of this book: Pach et al. 2021).

- Relate any data produced for productive purposes along the timber supply chain (from stump to mill) to the stand and single tree health and physiology data gathered in the frame of CSF studies.

Tracking systems are common in industrial applications, but to automatically identify single logs throughout the forest supply chain is a challenging task. In timber supply chains, several handling operations may be involved (such as skidding, loading, piling, etc.), causing mechanical impacts and frictions. The capacity of tags or marks to remain attached to the logs is further hindered by the exposure to weather factors, such as rain, frost, and sunlight exposure. These factors, together with the presence of mud, dust, or resins and with the very variable conditions of natural illumination, may challenge readability of ID codes in the case of visual systems. Additionally, the tracking service should be based on unique codes (physical ID number) linked with an ID code stored in a database, allowing it to retrieve the attributes associated with each timber item. A further requirement is that the system must be reliable and relatively inexpensive, allowing to mark the ID of trees and $\operatorname{logs}$ without incurring in significant productivity losses for the forest operations. Finally, the stored information must be retrieved automatically at predefined steps of the chain supply with remote systems featuring reading ranges above $1 \mathrm{~m}$ (Korten and Kaul 2008). 


\subsubsection{Current Marking Systems}

At present, several simple marking and tracing systems are used in forest management and timber production activities. This is the case in most of the Alpine region, where trees selected for felling are manually marked with log brand hummers in the frame of close-to-nature silviculture (Fig.9.3). In the simplest case, the tool is used to debark a spot of the trunk, creating a mark easily detectable by the chain saw operators. The forester uses the brand, featuring a personal and unique shape, to mark the stump of the tree and certify the selection made. This makes it possible to identify any tree felled other than the selected ones and detect illegal or unauthorized logging.

Due to their low cost and relative robustness in identifying trees intended for timber production, log brands as well as paper or plastic tags are used by a large number of forest companies worldwide to mark trees in the forest but also logs at sorting yards (Murphy et al. 2012; Kaakkurivaara 2019).

Color marking is another very common system, thanks to its fast and practical application. Along with manual marking, color spray enables automated marking. This is done by processor heads equipped with spray nozzles, which quickly mark the processed logs with a combination of up to three colors (Fig. 9.4). The system is generally used to segregate assortments differentiated by length and diameter classes (e.g., pulpwood vs industrial timber), as measured by the onboard sensors

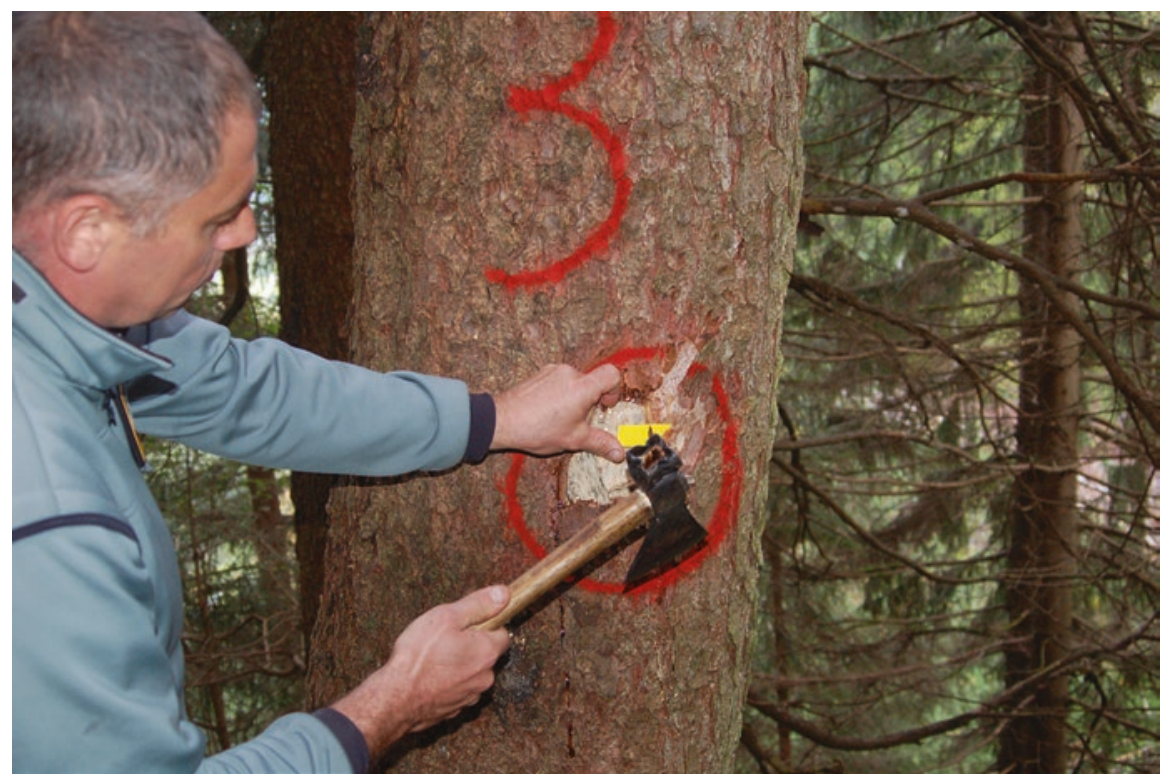

Fig. 9.3 Brand hammer used to mark trees. Note the area debarked with the sharp part of the tool and in the back of it the shape of the brand. Painting and yellow tags were part of a test and would not be used in common tree marking together with brand hammer 


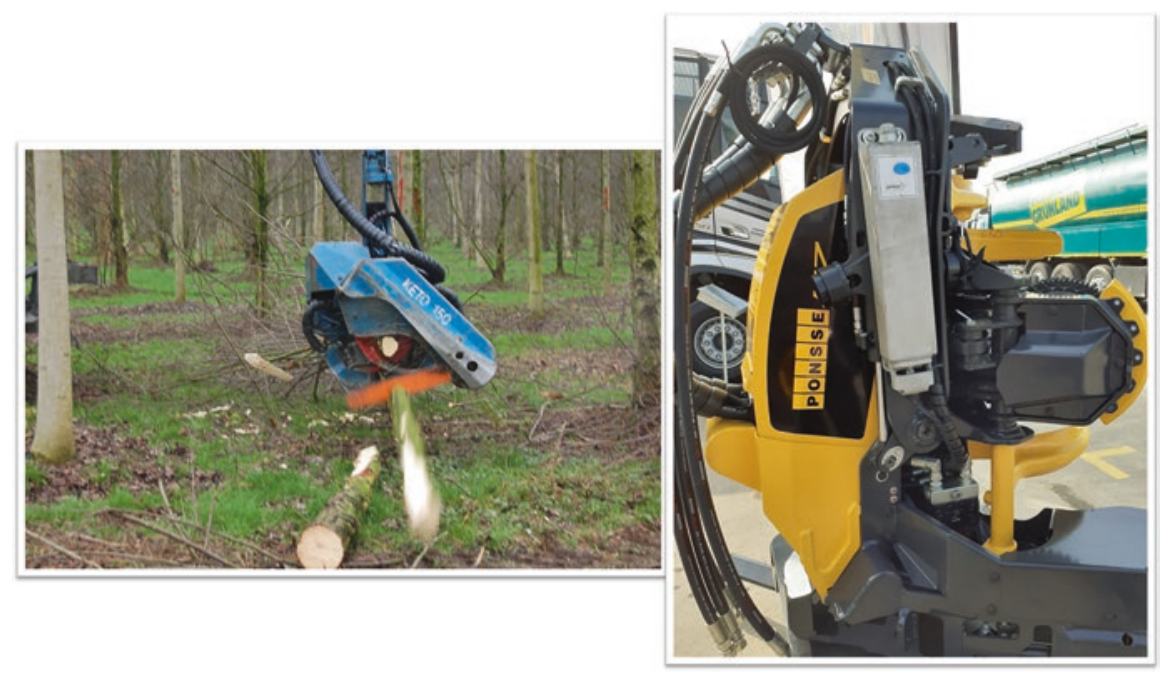

Fig. 9.4 On the left, a timber processor crosscutting a tree. Just after this operation, it is possible to mark the cut section with colors. On the right, a processor head equipped with color spray: the blue color tank is visible

simplifying the operations of hauling and piling per assortment. The solution is effective, but it requires visual identification and interpretation by an operator at each step of the process and carries no single-item properties.

In timber supply chains featuring assortments with high unitary value, it is quite common to individually mark each log. Traditionally, this operation is performed manually, and the characteristics to be associated with the log are measured and reported manually in a database. Log brands cannot be used for this purpose, as they cannot define a unique ID for each log. Thus, volume, quality class (based on visual evaluation), species, and forest lot of provenance are associated with a unique alphanumeric code printed on a plastic tag fixed on the log. This information is used to track the log along the logistic process and as a reference for purchasing and invoicing of the timber products. Nevertheless, in spite of their low investment cost, manual-based tracking systems are not sufficient to cope with the recent developments in forest equipment technology.

\subsubsection{Optical Marking Systems}

When using paper or plastic tags, all the process is manual, as well as the recording of codes at the different steps of the supply chain (e.g., delivery at the yard of the end user). This leads to possible errors while reading or noting the codes, but most of all, it is a time-consuming operation, which may significantly increase the cost of the final assortments (Kaakkurivaara 2019). In the attempt to facilitate its use, some 
producers print on the plastic tags both the alphanumeric code and a barcode, or just the latter which can be acquired with manual optical readers.

Several types of barcodes are in use worldwide, but the most common types are:

- Universal product code (UPC) with straight vertical lines. It is the most common, consumer-grade standard. The information is featured in a 12 numerical digit code.

- Quick response code (QR) which carries a much larger amount of information compared to the former.

Barcodes are relatively inexpensive as can be printed on any support, usually paper or plastic tags, and applied to the timber products. This technology requires visual connection for code acquisition with smartphones or portable devices, and effective reading can be hindered by inappropriate light conditions or presence of mud and dirt on the barcode. Furthermore, tags can be removed or damaged during handling and transport operations. This last inconvenience can be overcome printing the barcode directly on the wood surface. Spraying ID codes on wood boards is a common tracking system in industrial sawmills and has been successfully tested in forest operations by installing spray nozzles on the chain saw bar of a processor head (Möller et al. 2011). This solution allows to mark the crosscut section of each $\log$ with a special barcode while processing and without productivity losses (Figs. 9.5 and 9.6). Clearly, the system has several challenges, among which is the readability of a code printed on the relatively rough surface of a log crosscut with chain saw. Readability can be improved with the addition of microtaggants. These are microscopic particles to be mixed with the paint used for spraying. Being composed by different layers artificially designed, microtaggants provide a unique numeric code (visible with microscopic analysis), which prevents falsification and that may include materials that enhance readability when exposed to UV or laser light sources.

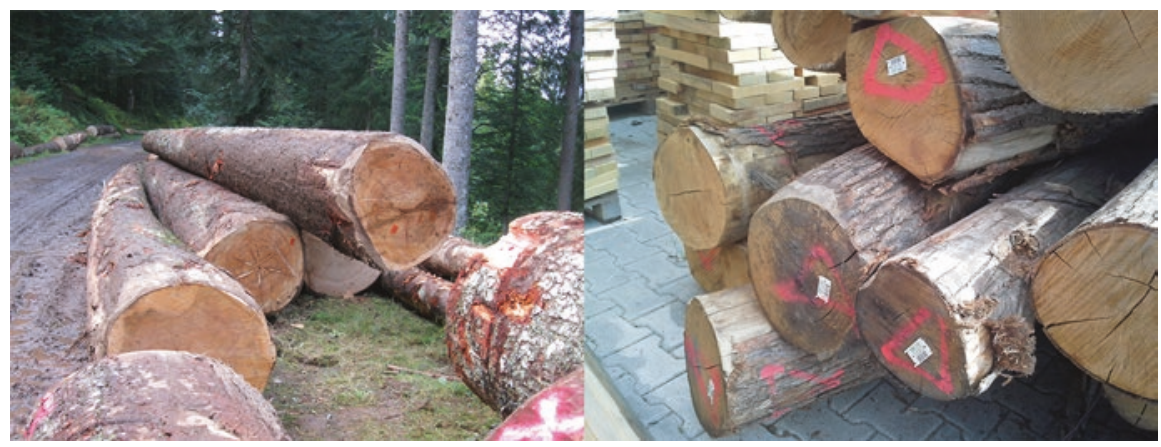

Fig. 9.5 On the left, logs recently hauled marked with plastic tags (orange). On the right, two models of plastic tags with numerical and UPC barcode 

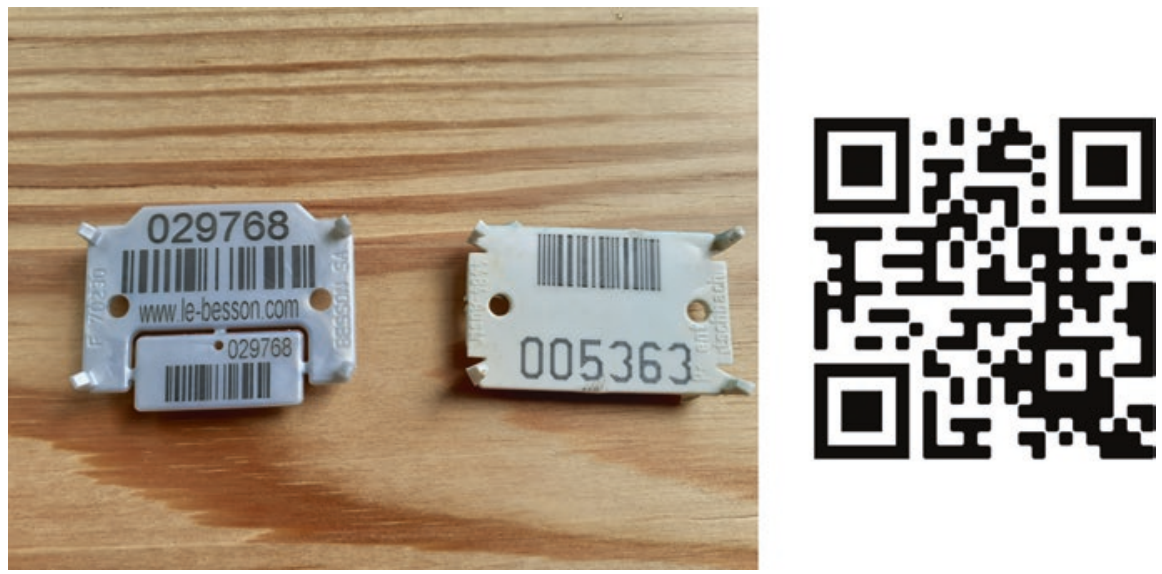

Fig. 9.6 Example of UPC barcode on plastic tags (left) and a QR code (right)
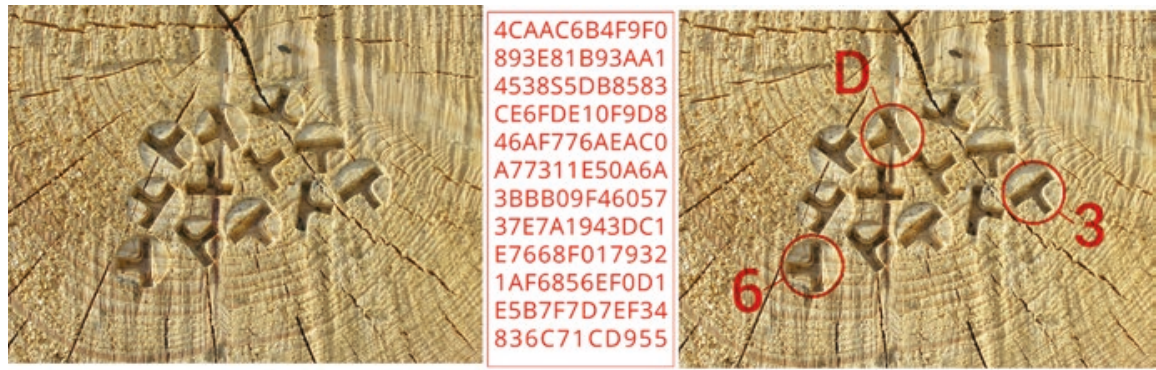

Fig. 9.7 The coded brands punched in the solid wood on the left carry an information carried as a unique ID for the log as simplified on the center and right. (Source www.otmetka.com)

A further development of the barcoding concept in timber industry is provided by the Swedish company Otmetka, which developed a dedicated solution for visually marking single logs. The system, called Woodpecker, is constituted by 12 hammer brands, which are punched into the wood by the harvester head. The hammers can independently rotate, and each position represents an alphanumeric value, generating a unique 12-digit code that identifies the timber item, assigning it an ID that allows retrieving its attributes in the associated database. The marks are impressed in the butt end of the log and can be read with optical technology and software elaboration at the sawmilling facility (Fig. 9.7). Also, this technology has been tested successfully on processor heads, leading to a fast and effective tagging of logs.

Another promising technology for timber tracking is biometrics fingerprinting (Murphy et al. 2012). This technology is based on the identification of the unique 
characteristics of each log end section (or crosscut section), identified through the analysis of digital images. The system is better suited for industrial, indoor applications due to the more controlled reading conditions (stable light, fixed angle, and distance of reading), but the implementation on processor heads has been conceived in order to secure a tracking service of single logs from the stump to the mill (Schraml et al. 2015). Biometric fingerprinting requires high-quality images of the $\log$ ends to discriminate logs. Common cameras providing images in the visible spectra can be deployed, but sensors operating in the hyperspectral and NIRs proved more effective (Schraml et al. 2020). Clearly, the file size of images would be too large to transfer it from the forest to a server and store it in a large database (e.g., storing data for all the logs produced annually by a company). The first elaboration can identify the key identity characteristics of the log end and store the information in much lighter vector files, which can be effectively transferred in a reference database (Fig. 9.8). Deployment of biometrics from stump to mill would provide useful data for the industry, for instance, sorting early in the supply chain the timber assortments, but with slight adjustments of the image analysis software, it would also provide relevant CSF information regarding health and development of the felled trees. Biometric fingerprinting technology is not yet at a commercial stage, but its fast development is expected to soon open a wide range of applications and services to the timber supply chain, forest management, and CSF.

In general terms, all optical systems share the same advantages and drawbacks:

Pros

- Excluding the capital investments, are low-cost solutions (printing material is relatively inexpensive).

- In the case of direct printing, punching, and biometrics, it leaves on the logs no undesired materials for the processing industry.

\section{Cons}

- Require visual connection and appropriate illumination conditions for a reliable reading

- Are sensitive to mud and dirt that can strongly reduce readability

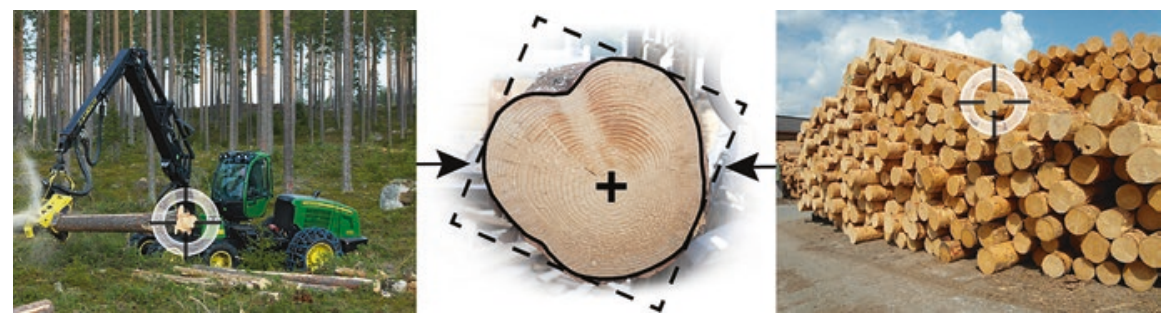

Fig. 9.8 Biometrics fingerprinting is based on the elaboration of visible and measurable characteristics of the log end, compressed in vector-format information. (Credit: Rudolf Schraml) 


\subsubsection{Radio Frequency Identification (RFID)}

Another promising technology for tracking timber products is provided by the radio frequency identification (RFID), based on the capacity to transmit information via electromagnetic waves. A typical RFID system is based on a reader connected to one or more antennas emitting an interrogating signal. The signal is received by tags attached to the item. Tags consist of a transponder and a chip and can be active (with an inner power source) or passive. The latter requires the energy provided by the interrogating wave to return a signal. By EPC standard, the signal returns the identity of the tag, stored in the 12-byte memory of the chip. Disposable, passive RFID tags are preferred in timber supply chains due to their low unitary cost, even if they can store less memory and feature a lower reading distance compared to active tags (Björk et al. 2011). RFID can operate at different frequencies, ranging from low (LF), high (HF), to ultrahigh (UHF). The latter allows effective reading ranges of several meters in operative conditions with passive tags (Tzoulis et al. 2014; Kaakkurivaara and Kaakkurivaara 2019). RFID tags had been successfully used to transfer throughout the sequence of forest operations the valuable information provided by inventory data elaboration, such as bucking instructions for maximum value recovery (Picchi et al. 2015).

Among the main advantages of RFID tags in forestry applications, there is the possibility to perform fast and effective bulk reading (e.g., a whole truckload passing through a mill's gate). Furthermore, they can be used both to mark standing trees (Picchi 2020) and processed logs. Therefore, RFID technology can provide a complete service of timber traceability, which may be a powerful tool in the frame of a chain of custody service, guaranteeing the sustainable production of timber products from the forest to the sawmill and up to the end user (Appelhanz et al. 2015).

Regarding the drawbacks, currently (year 2020) the unitary cost of disposable UHF-RFID tags is relatively high. For custom-made tags, it ranges around 0.6-0.27 $€$, respectively, for batches of 5000 and 100,000 units (Picchi 2020). Furthermore, mills could be unenthusiastic to deal with tags made of plastic and metal, even if their overall mass is about $1 \mathrm{~g}$. A possible solution could be the use of pulp-neutral material for the shell and radio-reflecting ink for the transponder, even if this would surely increase the cost of tags and probably reduce their performance (Fig. 9.9, Table 9.2).

Pros

- Automatic reading at high distances (3-5 m) of single tags or groups

- Reading not limited by presence of mud, dirt, or obscurity (Picchi et al. 2015)

- Possibility to manually or automatically tag standing trees and logs

Cons

- Unitary cost of tags may not be justified in case of low-value assortments.

- Disposable tags may be not accepted by end users of timber. 


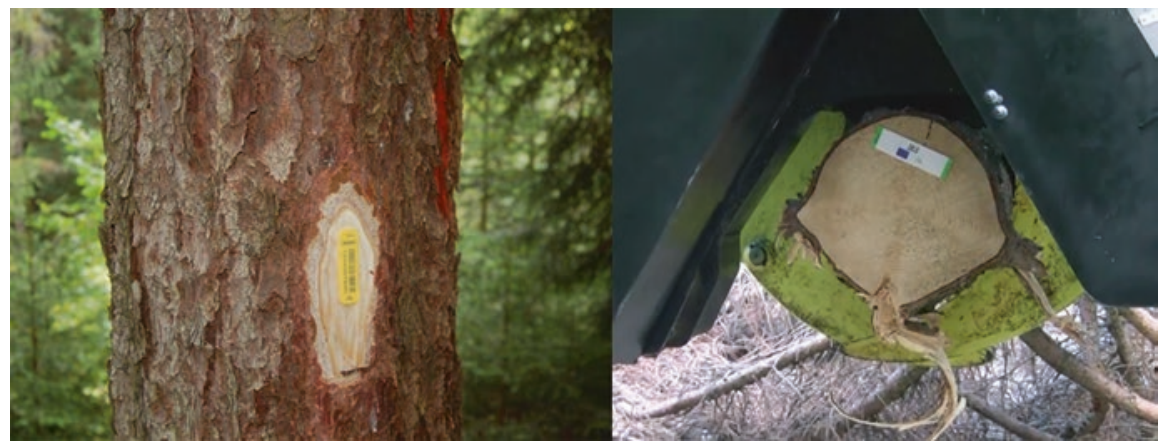

Fig. 9.9 On the left, an UHF RFID tag used to mark a standing tree, on the right an UHF RFID applied by the processor head after crosscutting

Table 9.2 Suitability of tracking technologies to applications in forestry and timber supply chains

\begin{tabular}{|c|c|c|c|c|c|c|c|c|c|c|}
\hline \multirow[b]{2}{*}{ Technology } & \multicolumn{2}{|c|}{ Item marked } & \multicolumn{2}{|c|}{$\begin{array}{l}\text { Application } \\
\text { method }\end{array}$} & \multicolumn{2}{|c|}{$\begin{array}{l}\text { Automatic } \\
\text { info retrieval }\end{array}$} & \multirow[b]{2}{*}{$\begin{array}{l}\text { Reading } \\
\text { range }\end{array}$} & \multirow{2}{*}{$\begin{array}{l}\text { Readable } \\
\text { with } \\
\text { mud/dirt }\end{array}$} & \multirow{2}{*}{$\begin{array}{l}\text { Resistant } \\
\text { to } \\
\text { hauling }\end{array}$} & \multirow{2}{*}{$\begin{array}{l}\text { Quantity } \\
\text { of stored } \\
\text { data }\end{array}$} \\
\hline & $\begin{array}{l}\text { Standing } \\
\text { trees }\end{array}$ & $\log s$ & Manual & Auto & Forest & $\begin{array}{l}\text { Yard/ } \\
\text { mill }\end{array}$ & & & & \\
\hline $\begin{array}{l}\text { Log brands } \\
\text { (hammer) }\end{array}$ & +++ & +++ & +++ & + & - & - & + & - & +++ & + \\
\hline Colors & ++ & ++ & +++ & ++ & - & - & ++ & - & ++ & + \\
\hline $\begin{array}{l}\text { Barcodes- } \\
\text { QR tags }\end{array}$ & +++ & +++ & +++ & +++ & + & +++ & + & - & ++ & +++ \\
\hline $\begin{array}{l}\text { Auto- } \\
\text { barcoding }\end{array}$ & - & +++ & - & +++ & + & +++ & + & - & +++ & ++++ \\
\hline Punching & - & +++ & + & +++ & + & ++ & + & - & +++ & ++++ \\
\hline Biometrics & - & +++ & ++ & +++ & + & +++ & + & + & +++ & + \\
\hline RFID & +++ & +++ & ++ & +++ & +++ & +++ & +++ & +++ & ++ & +++ \\
\hline
\end{tabular}

\subsection{Timber Industry as a Source of Data for CSF}

As mentioned in the previous section, the availability of a reliable tracking service discloses several new opportunities in timber supply chains. Among the most promising applications can be found the synergy between tracking technology and timber grading systems based on fast and nondestructive sensors. At present, these sensors find little application in forest operations: timber assortments can be sorted with machine support (e.g., using the StanForD data and dedicated software in the harvest machine), but quality grading of the logs is performed only visually. Nevertheless, this is a costly and time-demanding operation, which is potentially biased by the subjective judgment of the expert evaluator. 
Once in the industry, a large set of sensors is used to precisely quantify the volume of the logs delivered and its quality. Additionally, an increasing number of sensors or analytical techniques are used to optimize the following steps of product transformation in the sawmill or pulp mill. According to Gergel et al. (2019), the sawmilling optimization made possible by a detailed knowledge of the properties and defects of single logs leads to an increased value recovery of $15 \%$ and $23 \%$, respectively, for conifer and broadleaf timber. The same authors also highlighted how the status and quality of the standing trees prior to harvest plays a role of the utmost importance in the efficiency and economic balance of the timber supply chain. Nevertheless, in real practice, just empirical sorting models are used for inventorying trees according to their economic value. These return the share of predefined timber assortments with an intrinsic inaccuracy due to the impossibility of detecting internal wood defects from external features. A wide range of sensors could contribute to provide this service early in the supply chain. Their potential is maximum when different sensors work in synergy, contributing to generate a wide and comprehensive picture of the timber quality, for instance, integrating stem shape characteristics as returned by a TLS system (e.g., taper, straightness, crown insertion, etc.) with internal properties as detected by optical sensors on the felled trees (e.g., rot, decay, eccentricity, etc.). In the short term, the fusion of such data provides a more detailed definition of quality of single logs. In the long term, optically sensed characteristics may be used to tune the models interpreting 3D data provided by laser technology, gradually but constantly decreasing the gap between estimated properties and actual characteristics of the assortments. The very same data and approach can also disclose the "memory" of timber, being this the result of the growing conditions that the tree endured along its life. Widening the scope of the data analysis and the inputs of the models, it will be possible to support CSF studies and forecasts by relating the captured wood characteristics with the physiology of the trees and their response to the past stresses.

A recent trend in timber characterization is to deploy sensors as early as possible in the timber supply chain. Although application of timber quality gauges in forest machinery is mostly at the experimental stage, it arises great interest from the industry, since quality determination early in the supply chain would allow a great reduction of procurement costs by delivering just the desired quality to each end user, optimizing the logistics and further increasing the profitability of the industrial transformation. At the same time, the application of sensors for timber quality along the timber production process would bring additional benefits also to CSF applications, providing more data and with higher level of detail.

In addition to UAVs, forest technologies for monitoring tree processes include sensor networks deployed on the tree stems or embedded in the soil layers. The proliferation of these technologies generates a flow of data, which needs to be appropriately investigated through machine learning for automating or responding to disturbance events. The digitalization of forest stands allows forests to operate as technological platforms so that trees function as technical instruments informed by data that are meant to enable precision forestry and practices oriented toward high timber quality. 


\subsubsection{Wood Properties Relevant for CSF}

The industrial conversion of timber highly relies on the intrinsic characteristics and technical properties of this resource, which may be advantageous (or not) depending on the downstream process applied. The set of properties defining the quality of wood must be determined against the industrial requirements, local policy, and environmental constraints to assess its market value.

In a theoretical approach, a healthy tree results in production of the "perfect wood" defined here as a bioresource without wood defects. Perfect wood corresponds to the cylinder with a pith positioned in its geometrical center and containing regular concentric structures corresponding to yearly rings. In practice, perfect wood does not exist and always includes some defects. Here, the "defect" is considered as an undesired imperfection of the regular wood tissues that is a result of diverse stresses and factors affecting tree growth and the morphological constitution of the plant. Such natural features may be highly undesirable, downgrading the industrial value of timber. An example could be a knot that is an imprint of the branch positioned in the trunk. Branches cause the presence of knots that deviate the fiber direction, having a tremendous effect on the mechanical properties of timber, as well as tree stability.

\subsubsection{Tree-Ring Structure}

In temperate forests, the life of trees covers a sequence of several seasons that are recorded in the tree rings. These are structural wood tissues of different properties in spring/summer (early wood) or autumn/winter (late wood). The ring width, its chemical composition, microfibril structure, as well as the ratio of late to early woods may vary, depending on the age of tree, meteorological history, or presence of diverse factors stimulating or inhibiting the tree growth. The natural yearly sequence of air temperature, solar light photoperiod, as well as water stress levels are expressed as the dynamical changes of the phenological events determining specific xylogenetic sequences. Therefore, the tree-ring structure may be considered as a "fingerprint" unique for each plant. This can be used for dating of wood (dendrochronology), determination of the wood origin (dendro-provenance), analysis of the local climate changes (dendro-climatology), or identification of catastrophic events, occurring during the life span of the tree, among others. As such, tree-ring analysis can be considered as one of the most important inputs for the tree growth and health models developed in CSF (see Chap. 7 of this book: Bosela et al. 2021).

Traditionally, tree-ring analysis was performed by visual (microscopic) assessment of tree core samples extracted from the living tree or on cross sections of the $\log$ after felling. For that reason, the amount of available information was relatively limited. However, several modern technologies, especially based on the tomography approach (Van den Bulcke et al. 2014), allow mapping of the tree-ring 
structure without necessity for its cutting or extracting samples. Mobile X-ray computed tomography technology was applied in wood density measurements and moisture content monitoring on standing trees (Raschi et al. 1995; Tognetti et al. 1996). Computer 3D tomography allows locating internal log features that include pith, sapwood, heartwood, knots, and other defects. With the appropriate techniques, it can also return a detailed analysis and densitometry of annual growth rings (Van den Bulcke et al. 2014). Additionally, spectroscopic methods as well as its evolution by means of hyperspectral imaging (Sandak et al. 2020; Schraml et al. 2020) provide a possibility for extraction of till-now not accessible information regarding chemical and physical properties of wood resolved spatially to the treering level.

Nevertheless, from a technical perspective, it is crucial that both the quality of the acquired images and the capacity of the interpretation software provide sufficient information regarding tree rings of the logs (Subah et al. 2017; Cruz-García et al. 2019). The sensors installed on the processor head and operating in the forest on unprepared surfaces (the chain saw cutting surface is relatively rough for this use) may be incapable of returning the required quality for a deep and reliable analysis. On the other hand, they would potentially provide a large dataset, based on all the logs produced in the forest, including those with defects. This contraposes to the higher potential of industrial timber analysis, where more powerful sensors, deployed in a controlled environment, can provide extremely detailed data. Once set up, an automated tree-ring analysis, linked with an effective traceability system, would provide a very large volume of data. Such information may prove extremely valuable for understanding the past dynamics of relatively large areas of forests or to refine and better elaborate the information provided by dendrometers installed in monitoring plots (Cruz-García et al. 2019). For instance, the availability of a large dataset reporting growth pattern of trees of the same species growing in different areas allows to better understand the seasonal and site-specific growth response to drought (Mina et al. 2016) or human-driven factors, such as pollution (Innes and Cook 1989) or wildfires (Walker et al. 2017). This information can be further elaborated, helping to understand the response to stress of forests with different characteristics, such as density (Sun et al. 2020) and elaborate guidelines for CSF implementation. Although measurements of stem growth characteristics in temporal detail (e.g., radial increment, slow vs. fast growing trees) are important to understand wood properties, these properties change during wood formation in response to changing environmental conditions. Indeed, vessel conduit dimensions, cell wall thickness, and the relative proportions of different xylem cell types vary during the growing season. Changes in stem size detected through dendrometers can be associated with tree water status (Zweifel et al. 2007), with daily fluctuations being related to physiological parameters (e.g., leaf water potential, whole plant transpiration) and environmental conditions (e.g., evaporative demand and air temperature) (Giovannelli et al. 2007; Tognetti et al. 2009). These stem radius changes provide a sensitive indicator of the combined effects of actual radial growth and stem water storage and release (Drew and Downes 2009). Stem size variation provides indications of water stress 
thresholds in tree species and is potentially useful in threshold analysis for binary classification and determining the influence of thermal or moisture cycles on elastic shrinkage (Cocozza et al. 2009, 2012). Coding of the dendrometer signal helps quantify stem (or $\log$ ) sensitivity to environmental fluctuations (moisture, temperature), as well as synchronize time series related to wood properties and climatic events, and to identify time lags of environmental effects on wood traits (Cocozza et al. 2018).

Ideally, the study of tree reactions to stresses should be based on the analysis of tree-ring development of trunk sections located at different heights. In fact, while the common dendrochronology focuses on basal sections, where all the rings are represented (since the early development of the tree), in physiology studies, the rings grown higher in the tree's crown may better describe the stresses suffered by the plant. For instance, in the case of Picea abies growing in the Alps, the phloem's growth at the base of the trunk is completed already in July, while at higher levels of the tree, it keeps growing for the whole summer. Thus, the rings developed higher on the stem provide more effective evidence of the growing conditions of the mid-late growing season. If the tracking system records the order of production of each log, their original position in the trunk can be located and the sawmill's data (e.g., tomography) can be related to sections corresponding to different heights of the tree.

\subsubsection{Timber Density}

Density of wood (or specific gravity) is a metaparameter determining several technical characteristics of natural resources, considered as the most relevant wood quality descriptor (Zobel and Jett 1995). It expresses the amount of wood substance contained in a given volume. Even if density is not directly affecting wood properties (it is a property quantifier), it is highly correlated to the majority of wood assets (chemical, physical and mechanical), the yield of production, and the overall "wood quality" in general. The density distribution differs within a single plant, both along the tree height and the trunk diameter. Despite being a property of remarkably high native variance and heritability, it can be related at stand level to growth conditions or silvicultural interventions (Briggs et al. 2008), thus providing valuable information if appropriate reference values can be defined. Density is often measured in sawmill, but the interest to discriminate the timber products with the desired properties as early as possible within the supply chain stimulated the development of portable instruments. These can be deployed both for assessing the characteristics of standing trees (Paradis et al. 2013) and for automatically measuring each log with gauges installed directly in the processor head (Walsh et al. 2014a).

The effect of tree-ring width on tree-ring wood density depends on the species (conifers vs. broadleaves, fast- vs. slow-growing species), the timing of climatic events influencing growth throughout the growing season and the general fertility of the site. In particular, intra- and interspecific interactions may affect the radial 
growth and wood density of individual species growing in mixture when compared to its monoculture (Zeller et al. 2017). The acoustic sensing technology, such as the modulus of elasticity of wood (MOE) and the dynamic modulus of elasticity (MOEd), allows the estimation of intrinsic wood properties for standing trees, stems, and logs. These parameters depend on wood density and are fundamental for the evaluation of wood quality, providing information related to wood anatomy and tree physiology (Russo et al. 2020).

\subsubsection{Chemical Composition of Wood}

From the chemical viewpoint, wood is a natural composite of three biopolymers, including cellulose, lignin and hemicellulose. These are major constitutive chemical components, with their specific ratio varying between wood species, forest types, and within individual trees. In temperate areas, the chemical composition differs substantially along the tree height and its radius following the natural lifetime sequence of the periods when the tree grows fast (spring) or forms more mechanically resistant morphological structures (autumn). The variation of chemical composition can also be noticed at the level of the yearly ring that reflects the combined effects of the season and plant development stage as well as any other stresses for the tree due to biotic or abiotic factors. In addition to cellulose, lignin, and hemicellulose, small amounts of minerals and extractive components are present in natural wood. The latter are particularly relevant despite their low concentrations. In fact, extractives may significantly affect the suitability of wood resources for a given conversion process or affect the durability of wood-derived products.

All the chemical components form larger macromolecules, such as microfibrils, that are combined at different scales as fibrils, cells, and yearly rings constituting a hierarchical structure. The specific physical properties of wood are, therefore, highly dependent on the scale of observation (nano, micro, macro). It implies the necessity for adjusting measurement procedures and instrumentation for determination of desired chemical/physical characteristics and material properties. Such information has not yet been used for CSF applications. This is probably due to the cost and time delay of wet chemistry analysis. The availability of fast and nondestructive sensors, such as hyperspectral cameras, may disclose a new source of information to understand the health and growing conditions of trees.

\subsubsection{Wood Defects}

In contrast to the perfect wood, the real trunk contains diverse imperfections recording all the lifelong-related growth conditions, perturbations, or stresses. In the timber industry, these are defined as wood defects and may include numerous features 
differentiating defected from the perfect wood (Kimbar 2011). The European standard EN 1927-1:2008 provides a systematic methodology for identification and quantification of the log/wood defects that are later used for determination of the quality class. The following sections report the most relevant defects from the perspective of CSF.

\subsubsection{Resin Pockets}

Resin pockets are small gaps within the structure of the xylem filled with resin. Wood development due to tree growth usually occludes them within a few years after their formation. Resin pockets are a significant technological defect for the timber industry, particularly for joinery and furniture applications, due to the release of resin over time from the finished products. Resin pockets are common in conifers with resin canals (such as Picea, Pinus, Larix, and Pseudotsuga genera) but may also be the consequence of stress. In the latter case, they are commonly related to animal or insect attacks, sites exposed to strong winds and storm damages. Research demonstrated that water stress is to be regarded as the most relevant factor leading to the development of this wood defect (Seifert et al. 2010; Jones et al. 2013), although other factors, such as excessive growth rate or share of defect core over total diameters at breast height $(\mathrm{DBH})$, may contribute to pocket formation (Woollons et al. 2008). Availability of data on resin pockets may be a useful tool for identifying historical occurrence of water stress, areas with frequent wind gusts, and, possibly, the impact of forest management on certain growing conditions. Clearly, the interpretation of resin pocket presence is much more significant if associated with other parameters detected by the sensors on processed and sawn timber, namely, tree-ring development. Furthermore, tree rings are present throughout the whole trunk, but their size increases from the base upward and from the core outward (Gjerdrum and Bernabei 2007). Thus, for a correct interpretation of their occurrence, it is important to know the position in the stem of the timber sample considered. This is possible only with an accurate traceability system capable of relating each log sourced from a tree with each other according to their sequential order.

Like resin pockets, resinous wood is a zone within trunk volume with exceptionally high content of extractive components and resins. It is present only in conifer species with resin channels. The usual causes for resinous wood formation are responses to the microorganism activity (especially parasite fungus) or to the damage of wood induced by mechanical actions. The analogy for self-protection by the resin release in some broadleaves is a gum production that can be triggered by the frost, wound, or microorganism attack. 


\subsubsection{Cracks}

Checks, splits, and shakes (commonly defined as cracks) are separations or ruptures of the wood tissue in the longitudinal plane that normally occur along fibers in the radial or tangential sections of the trunk. These may appear on the cross section of the tree or on the log side circumference. Checks are separations of the fibers that do not extend through the timber from one face to another. Splits, however, extend the material discontinuity from the one log face to another. Shakes are separations or weaknesses of fiber bond, between or through the annual rings. There are diverse sources of stresses occurring to wood during life cycle. The most relevant are growth and drying stresses, beside thermal, frost, wind-, solar-, or lightning-induced tensions. Shakes may originate from causes other than drying stresses, e.g., from careless felling, where internal stresses existing in the living tree are released when the tree is felled. Checks, shakes, and splits are present although they may not be visible (closed checks and closed splits). Cracks may close up if the dry timber is subsequently exposed to damp conditions, but once the fibers have separated, they cannot join together again. A great threat for the tree after a crack occurring is elevated risk of decay fungi spore access to the unprotected wood tissue. The presence of cracks is an important limitation for the downstream conversion, especially if combined with other defects, such as spiral grain. Due to specific properties, cracks are relatively easily detectable even if not visible on the surface of $\log$. This is due to the discontinuity of the material and related change of the material stiffness (natural frequency) or elasticity (stress wave propagation velocity).

\subsubsection{Reaction Wood}

Reaction wood is a type of defect that tends to form in trees growing in a leaning posture. This may be caused by exposure to strong winds or because the tree grows on a slope. Reaction wood in coniferous trees is formed on the lower side of the lean and is called "compression wood." It is often characterized by a dense hard brittle grain that contains very high content of lignin that increases wood resistance for compression. On the contrary, the broadleaves create reaction wood referred to as "tension wood" that is positioned on the upper side of the lean. It contains higher content of cellulose that increases wood resistance to tension stresses. Properties of compression wood are considerably different from those of normal mature wood. Compression wood tracheids, for example, are about $30 \%$ shorter than normal. In addition, compression wood contains about $10 \%$ less cellulose and 8-9\% more lignin and hemicelluloses than in normal wood. These factors reduce the desirability of compression wood for pulp and paper manufacture. It is also less suitable as sawn timber since it shows a lower strength, stiffness, and dimensional stability, resulting in a decrease in yield of high-quality end products.

Data related to reaction wood can be a particularly useful tool in the frame of CSF in mountain areas, as it records specific reaction of trees to environmental 
conditions. According to Łszczyńska et al. (2019), data regarding the frequency and characteristics of reaction wood in forested plots may be used to assess the landslide hazard risk. In fact, in case of slight land movements, trees are tilted causing leaning and thus the formation of reaction wood. The same phenomena also lead to the formation of eccentric piths, which can be detected by tree-ring analysis. The vertical stability of a tree can be assessed using an automatic accelerometer (gyroscopic sensor), which measures the position and oscillation in three axes (Matasov et al. 2020), therefore, providing useful information on the effect of wind exposure on the tree aerial architecture and species-specific biomechanics.

\subsubsection{Rot}

Fungi decay is considered as the most problematic biological threat degrading wood at all stages of its life cycle, including postharvesting. Due to its chemical composition, wood is an optimal source of nutrition for fungi and, therefore, it will be a subject of extensive degradation whenever favorable conditions for growth of fungi occur. These include temperature ranges from 20 to $30{ }^{\circ} \mathrm{C}$ with a wood moisture content ranging from 20 to 50\%. Diverse species of decaying fungi are specialized in degradation of specific wood polymers resulting in different degradation results. This led to the classification of fungi into three major groups: white rot, brown rot, and grey rot. The fungi spores may access wood by several ways, including root, broken branch, damaged leader, or scar on the stem. Cracks, wounds, or any other exposed surfaces of the wood. The presence of birds nesting in hollows in the tree is a certain sign of the progressing decay deterioration. Rot is the wood defect for which the quality grade reduction is obligatory. Logs cut out from older trees are more likely to contain developed rot. The final stage of rot is a complete or extensive material loss forming internal cavities. Plants have developed several mechanisms to defend themselves against decaying fungi. For instance, diverse chemical substances synthetized by trees are natural biocides, such as tannins, resins, or gum.

\subsubsection{Knots}

A knot in the tree is the portion of a branch or limb that has been surrounded by subsequent xylem growth during the tree life. Knots form morphological structures starting from the pith and by following the radial direction reaching the log surface. There are more than 50 types of knots that are classified according to the size, decay presence, and location and distribution within the stem.

The size, type, and distribution of knots have the most important impact on log quality and are the main consideration when applying grading rules. The severity of the grain deflection caused by the knot is correlated with its size. In any case, the presence of knots changes the anatomical structure of surrounding wood 
(reaction wood presence and grain deviation), as well as its chemical composition (extremely high content of extractive components). The distribution of knots in $\log$ s depends on the species and characteristics of the growing site. It is also determined by the growth characteristics of the tree and the tree age. The detailed knowledge regarding knots in trees is highly relevant for CSF. Fortunately, there are several scanning techniques for automatic detection and classification of knots that are implemented during forest operations, log sorting/grading, as well as downstream conversion.

\subsubsection{Shape Imperfections}

Any deviation of the tree form from the perfect cylinder is considered as a shape imperfection, reducing the yield of product that can be obtained in the sawmill. Sweep, excessive taper, bulges, swell, flanges, and out-of-roundness are some of the most important shape imperfections. All these defects can be measured both on the standing tree and on the processed log by means of laser triangulation scanners, photogrammetry, and TLS. In some cases, imperfections can be reported also by the standard measurement equipment installed on most modern timber processors.

Sweep is a bow-like bend in the trunk of a tree diverging the trunk from the straight and vertical theoretical axis of the tree. The presence of sweep is a result of diverse factors, including slope of the terrain, temporary loading due to snow or wind, mechanical damages, or insect activity.

Tree taper is defined as the gradual reduction of the log diameter along its length. It is a natural feature of each living tree, even if logs with a high degree of taper are considered as having a poor form. Although taper cannot be eliminated, it is possible to minimize it by means of appropriate silvicultural activities. In fact, the extent of taper depends not only on the tree species, local climate, age of the tree, soil fertility, and terrain irregularity but also on the density of trees within the surrounding forest stand.

Bulge is an enlargement of the tree diameter forming a barreling shape. It is a natural feature when occurring at the bottom of the tree, assuming reasonable progress of the diameter changes. On the contrary, when occurring in the higher part of the trunk it is frequently associated with fungi or bacteria attack.

Canker is a defected wood in a form of gnarls or volume losses, both attributed to the phytopathological changes triggered by an activity of microorganisms (fungi or bacteria). In contrast to swollen wood, the tissue of the canker is abnormal and sick.

Out-of-roundness is a shape imperfection appearing as an elliptical cross section of the log. It is frequently associated with the eccentric or double pith. The usual consequence of the pith shift is the presence of reaction (tension or compression) wood. Another reason for the out-of-roundness is the partial damage of the cambium due to mechanical or phytopathological injury.

Such stem defects can be related to the influence of various environmental factors, supporting CSF studies to better understand tree growth dynamics. According 
to Schneider (2018), the hydraulic and biomechanic theories are the most widely used. Both theories underline the importance of crown dimensions in determining tree form, as confirmed by Kidombo and Dean (2018). Yet, climatic variables such as total summer precipitation and mean winter temperature may have a higher influence on tree taper than the average wind speed (Schneider 2018). This underlines that the complex tree growth dynamics require a holistic analysis of all climatic factors and physiological processes to understand stem formation.

\subsubsection{Sensors for Timber Quality Assessment}

Once the timber reaches the mill, a large array of possible sensors can be deployed to analyze the quality and volume of the logs to be processed. There are several technical solutions available for wood defects detection or quality grading of logs. Some of the most compatible with CSF requirements are presented in Fig. 9.10.

The length of log combined with its diameter is a basic merchantable property. As mentioned in Sect. 9.4.2, all the processors used for trees harvesting and delimbing are equipped with a measurement wheel and optical encoder (Mederski et al. 2018) (Fig. 9.10a). Sensors used for log diameter measurements are usually absolute encoders configured as protractors, which are integrated with both delimbing knives and feed rollers and measure these rotation angles (Fig. 9.10b). An advantage of such a measurement system is a possibility for a continuous determination of the diameter change trends along the three when passing the processor head. Combined length and diameter measurements provide not only highly precise information regarding a single log volume but can also quantify taper. Such a measurement approach is capable of fast data acquisition and straightforward integration with a database when converted to StanForD file format.

The light curtain is a simple optical measurement system, where the dimensional information regarding the object is determined by illumination (or shadowing) of electronic photodetectors (Fig. 9.10c). It was a very popular solution for the size sorting of logs supplied to the sawmill. However, nowadays it is replaced by the $3 D$ laser triangulation systems relying on the image analysis of the structured light profiles (usually laser) that appear as deformed when observed from an angle (Siekański et al. 2019). The advanced analysis of the surface texture allows identification of some wood defects appearing as particular textures of the bark.

Implementation of $X$-ray scanners for monitoring of logs is the industrial solution for detection of the majority of wood defects not visible on the log surface (Fig. 9.10d). It allows for identification of deviations of the wood properties along the log, without the possibility to localize the depth position of each feature. For that reason, this setup is frequently duplicated to provide a possibility for better recognition of the defect location within the log section. The ultimate solution for the X-ray imaging of logs is $X$-ray computed tomography (CT) scanner (Fig. 9.10k). This 
technology allows straightforward detection and mapping of internal defects, such as butt decay, voids, cracks, or inclusions. The resolution of images allows dendrometric analysis of tree rings and other refined measurements (Van den Bulcke et al. 2014; Stängle et al. 2015; Rais et al. 2017; Gergel et al. 2019). Appropriate data analysis may allow for the information collected on the logs to be related back and integrated with the information on the original tree. An example of this application is provided by Stängle et al. (2014), which compared data from TLS stem and branch scar analysis with X-ray computed tomography (CT), and Uner et al. (2009) using X-ray CT to highlight the effect of thinning on timber density. Thanks to the presence of several X-ray CT operatives in sawmills around the globe, and to their high-speed analysis (up to $180 \mathrm{~m} / \mathrm{min}$ ), this technology is a highly promising data source for CSF applications.

As in the case of drilling resistance, it is possible to indirectly assess mechanical strength of wood by measuring cutting forces occurring when crosscutting logs with a chain saw (Fig. 9.10f). This can be implemented by integrating load cells with the cutting unit or by measuring other effects, such as electrical power consumption or oil pressure changes in the hydraulic circuit of the saw motor (Sandak et al. 2019). Another possibility for adopting cutting resistance analysis for log characterization is to measure the forces required for delimbing. It is clear that a healthy and big branch results in much higher cutting resistance than delimbing of the small and dry branch. In any case, value obtained for a chain saw or delimbing knife can be considered only as an estimate and indirect quantification of the wood suitability; however, it is useful to identify some critical wood defects, such as decay or butt rot.

Stress wave propagation velocity is a highly useful tool for identification of the stiffness and modulus of elasticity (Walsh et al. 2014b) of logs derived from harvested trees (Fig. 9.10g). In that case, the sensor can be installed directly on the processor head and perform analysis before a crosscutting operation. A similar approach is used for determination of the mechanical properties of logs by measuring these natural frequencies. In that case, the log is induced to vibrate by an impact, and the vibrational or acoustic response is measured with specific detectors (Fig. 9.10h). These systems can be implemented both, as a part of the processor head configuration or component of the log sorting line in the sawmill.

The advanced algorithms used in image analysis enable mimicking of human vision and thus more effective automatic detection of wood imperfections or presence of defects. Other uses of the images is to implement a fingerprinting approach for log traceability and authentications (Schraml et al. 2020). The scanning with cameras can be performed on the log crosscut end (Raatevaara et al. 2020) (Fig. 9.10i) or on the side of the log (Shenga et al. 2015) along its circumference (Fig. 9.10j). The spectral information collected may include monochromatic, $R G B$ color, multispectral, or hyperspectral images. 

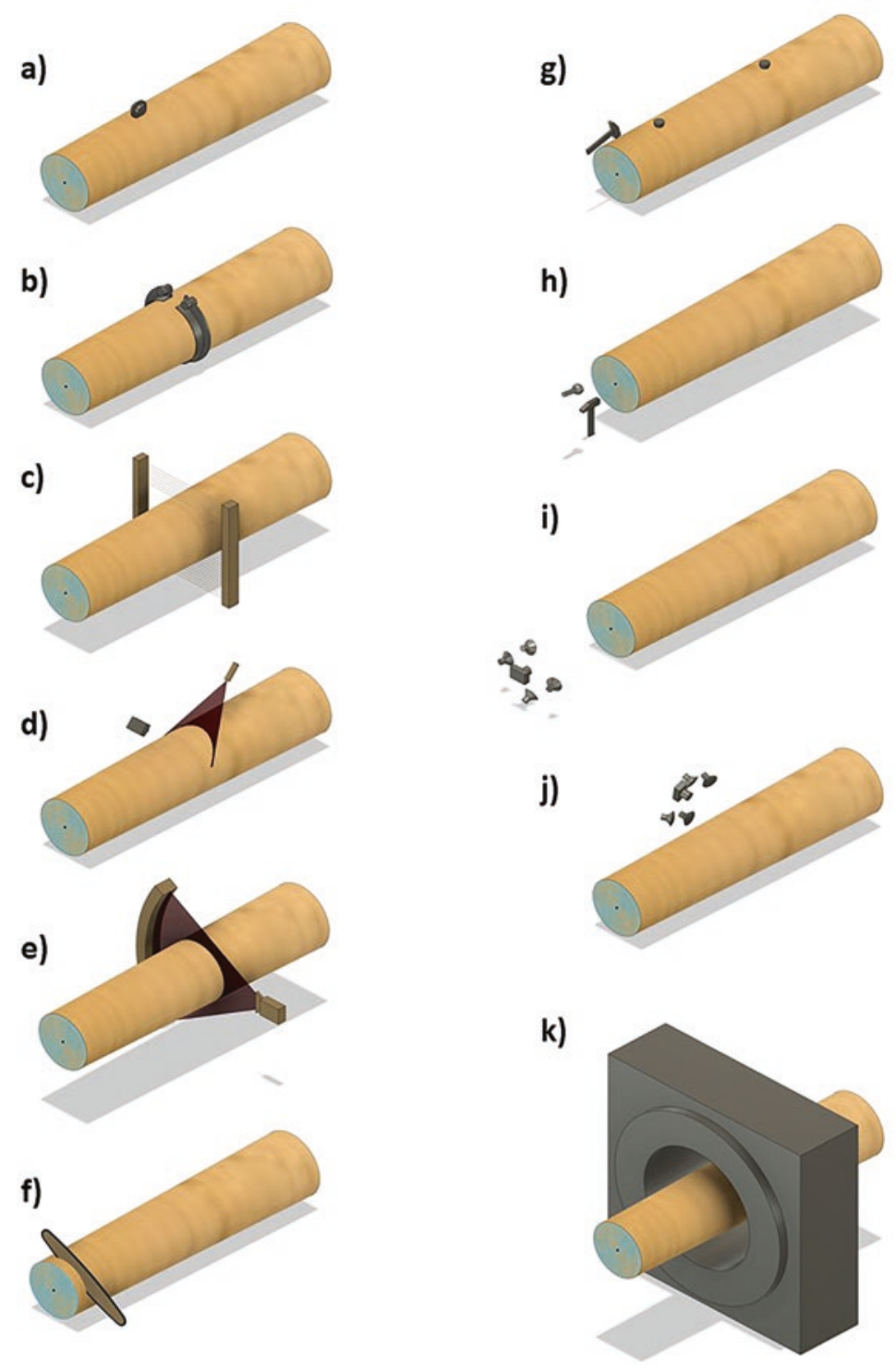

Fig. 9.10 Selected sensing techniques used for assessment of log characterization during forest operations and log sorting in sawmill: (a) measurement of lengths with rotary encoder, (b) measurement of the log diameters profile by two encoders integrated with debranching knives, (c) measurement of the log diameter with light curtain, (d) 3D log surface scanning with laser triangulation system, (e) determination of the X-ray attenuation for internal defects detection of density profiling, (f) measurement of mechanical properties by assessment of cutting forces when cross cutting logs with chain saw, (g) modulus of elasticity assessment by stress wave velocity, (h) free vibrations for determination of modulus of elasticity, (i) camera vision system for cross section scanning, analysis of tree rings and fingerprinting of logs for traceability, (j) camera vision system for identification of wood defects present on the log side surface, (k) computed X-ray tomography for $3 \mathrm{D}$ visualization and detection of internal defects 


\subsubsection{Emerging Scanning Technologies}

The scanning technologies presented in the previous section represent the industrial state-of-the-art solutions and are commercially available on the market. However, there are several promising techniques with great potential for migration from the laboratory testing into practical applications both in forest and in timber transformation industries. Some examples of the most suited for the CSF are briefly described below.

Spectroscopy, including visible, near-infrared and mid-infrared ranges is an analytical technique quantifying interaction of the electromagnetic radiation (light) with the matter. The light can be scattered, absorbed, transmitted, reflected, or trans-flected from the measured surface. The specific pattern of that interaction is recorded as a spectrum. Light absorbance, especially in the infrared range, is highly related to the chemical composition (functional groups with dipole momentum) of the sample. Therefore, by assessing light spectra reflected from the wood sample, it is possible to determine its chemical composition and some physical properties. An extensive reference dataset and advanced multivariate data analysis are indispensable to assure the high reliability of prediction models (Sandak et al. 2016b). However, if properly calibrated, spectroscopic evaluation of wood can provide a rapid and very low-cost assessment of a broad range of the properties, including species, provenance, chemical composition, physical properties, or suitability for diverse conversion paths (Sandak et al. 2017). Portable NIR spectrometers even allow scanning of standing trees or fallen logs directly in forest (Sandak et al. 2016a).

An evolution of the spectroscopy toward a space resolved map of spectra is implemented as multispectral or hyperspectral imaging. The difference between both is in the number of spectral bands constituting the spectrum, that is, $<10$ in the case of multispectral imaging. This technology allows rapid mapping of the chemical properties of the material over the object surface (Thumm et al. 2010). There are several properties of wood that can be assessed with the help of this technique, such as moisture content, chemical anisotropy of the constitutive polymers at diverse heights of trees (Meder and Meglen 2012), and fiber angle direction (Ma et al. 2017), among others. The limitation of hyperspectral imaging is relatively high investment cost, fragility of the optical instruments when integrating with forest operations, and very high amount of generated data that requires refined IT systems and algorithms.

Only a few wood scanning techniques allow scanning of the bulk interior. In contrast to harmful ionizing radiation of $\mathrm{X}$ - and gamma rays, microwaves are considered as safe and easy to apply in the scanning systems. A great advantage is that, assuming sufficient power of emitter, microwaves penetrate wood bulk, and these interactions with the matter can be interpreted as attenuation, phase shift, or polarity change. These wave properties are directly correlated to the wood density, wood moisture content, and grain angle direction (Schajer and Orhan 2005). For that reason, it is possible to simultaneously measure all the above wood properties. Microwave scanners can be implemented as an array that, in consequence, allows spatially resolved maps of wood assets (Table 9.3). 


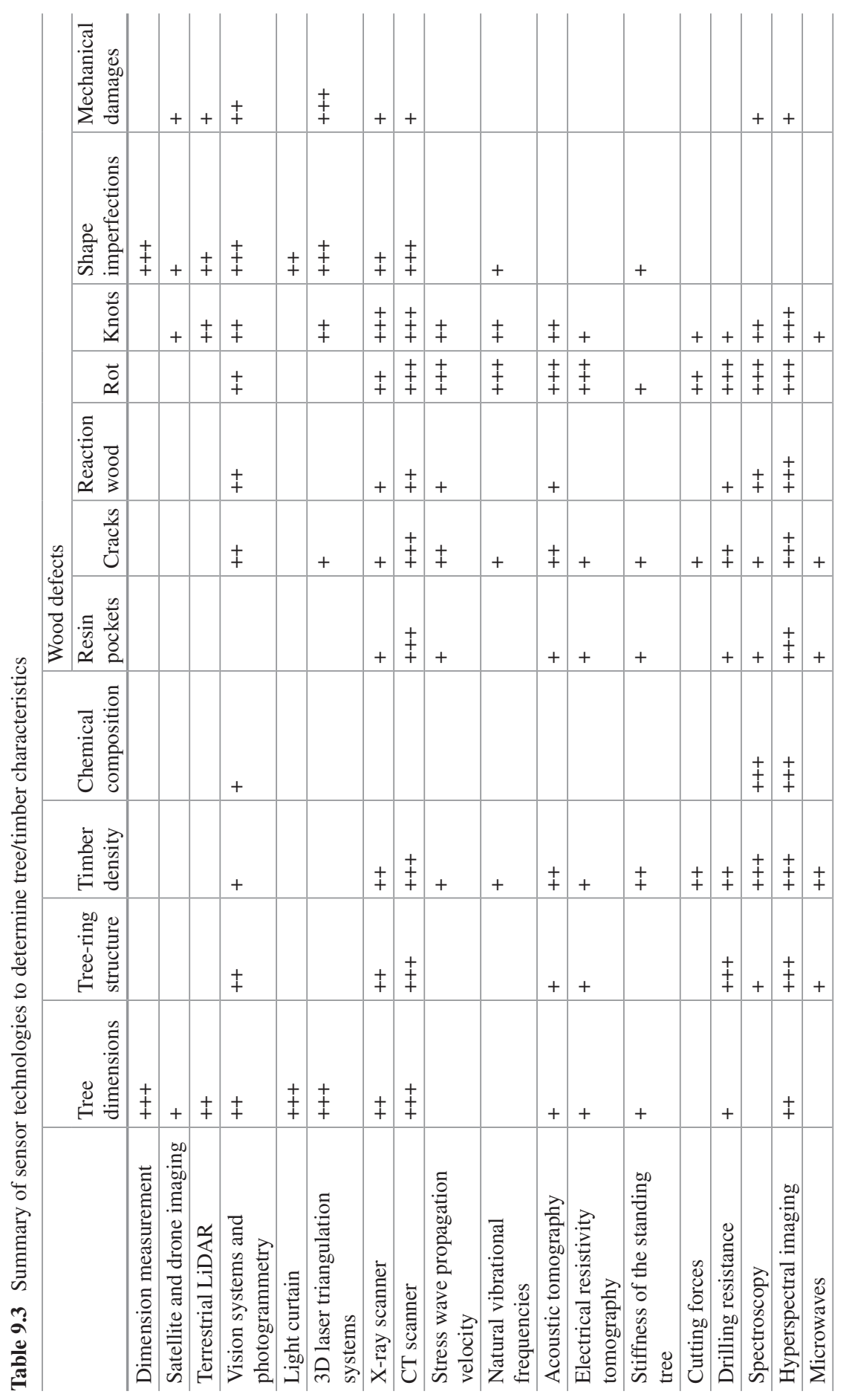




\subsubsection{Intelligent Forest Machines, the Way Ahead}

As described in the previous sections of this chapter, the availability of digital forest data makes it possible to optimize forest works from the operational cost and environmental impact point of view. Traceability tools further increase the precision of the operations and guarantee a full control of the woody products, whose value is effectively assessed and maximized by an array of sensors deployed in the mills. From the management (and CSF) point of view, the most effective solution is to link the databases of the forest inventories and the derived tracking systems with the log scanners operating at the sawmill. Nevertheless, a further significant improvement could be achieved with the determination of timber characteristics early in the supply chain, enhancing the sorting of logs and increasing the overall value of the derived timber products (Taube et al. 2020). The fast development of sensors makes this challenge possible, as it had been demonstrated by the EU project SLOPE (https://cordis.europa.eu/project/id/604129), funded under the seventh Framework Program. Within the project, the potential of the Virtual Forest, the tracking systems, and the timber sensors had been combined in a technological showcase, proving the feasibility of this concept.

The virtual forest was generated integrating information from satellite, UAVs, and TLS surveying systems, combining macro and local analysis in the characterization of the forest resources in mountain areas. Data was stored in a dedicated database provided with a 3D interface, which allowed users to navigate into the virtual forest, estimate the volume, and value of timber in a selected area as well as to plan accordingly the harvest operations by cable yarding (Fig. 9.11).

The cloud point generated by TLS surveys was used to characterize the trunks in high detail. A dedicated software matched the shape characteristics of the trees with the timber assortments and locally accepted their value, returning the maximum value recovery conditions. Those were appended in the database as bucking instructions to be transferred from the forest to the processor head. For this purpose, standing trees were georeferenced and marked with RFID UHF tags whose ID was linked to the data and bucking instructions of each tree (Fig. 9.12).

All forest operations were performed by prototypes of intelligent machines, namely, a cable yarder and a processor head operating at landing. The former detected the RFID and weight of the load, while the latter by reading the ID of the tree could acquire the crosscutting positions for optimal bucking. Additionally, the processor head installed several sensors for timber quality assessment as described in Sandak et al. (2019).

In detail, the processor deployed the following systems (Fig. 9.13):

- Load cells and hydraulic pressure sensors (1) for estimate of a branch index and the approximate position of knots on the trunk

- Stress wave and free vibration measurement systems (2) for timber density assessment

- Near-infrared (NIR) and hyperspectral imaging systems (3) for characterization of crosscut section and detection of defects (e.g., rot, resin pockets, etc.)

- RFID-UHF reader (4) for acquisition of tree ID and retrieval in the VF database of the cutting instructions elaborated for maximum value recovery 


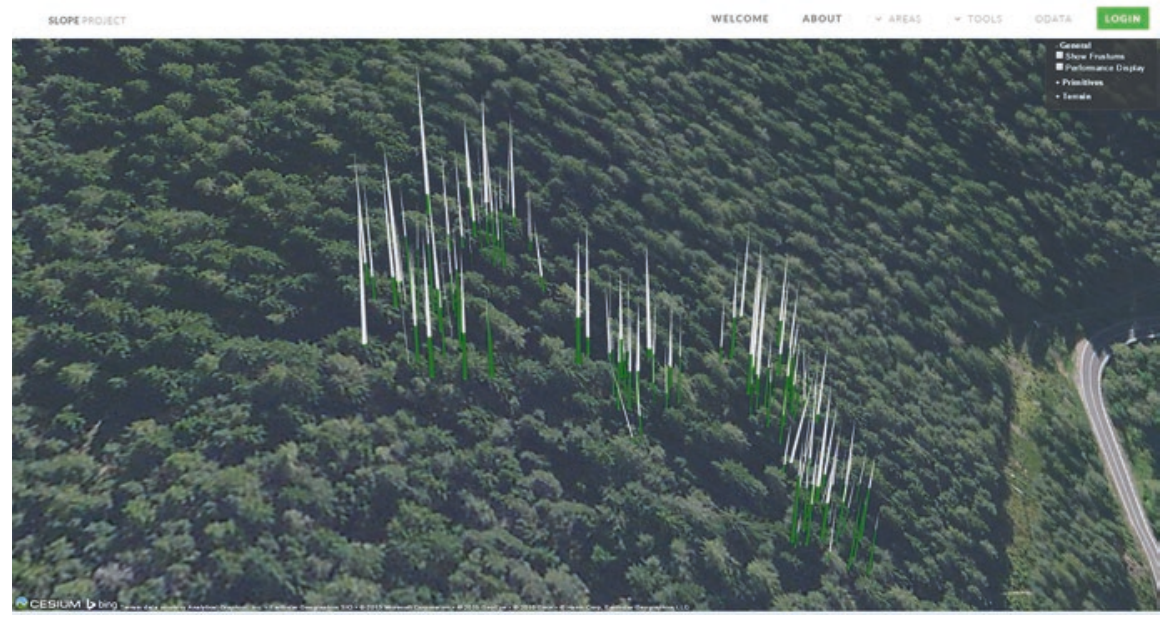

Fig. 9.11 3D visualization of forest (image combined with aerial picture). Marked trees are visualized in two colors: green for the trunk section detected by TLS and white for the estimate of the higher part of the trunk as estimated by UAV image analysis. (Source Project SLOPE)

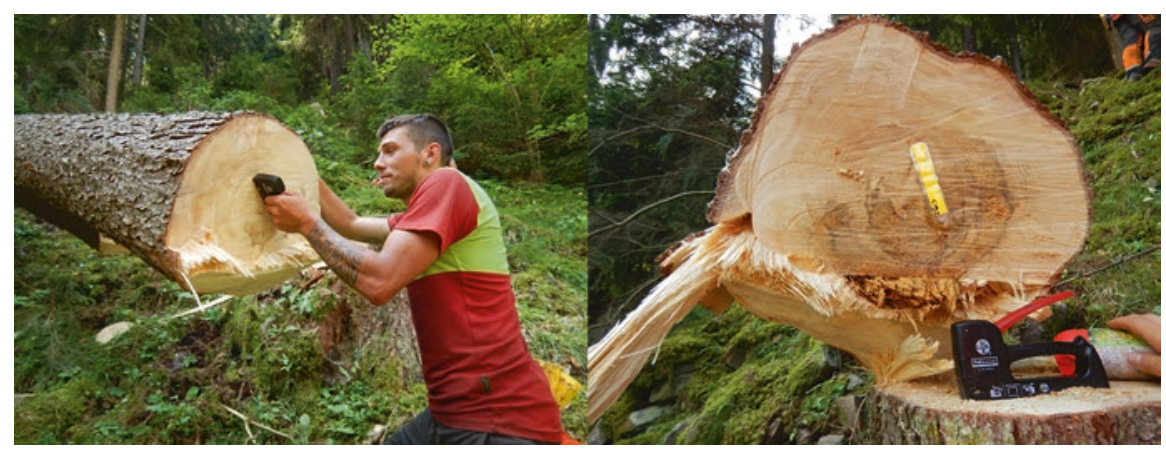

Fig. 9.12 Trees felled with motor-manual chain saws are marked with RFID for tracking along the supply chain and for transfer of cutting instructions to the processor head at landing

Additionally, the processor could mark each new log with an RFID tag, providing a complete tracking system capable of linking the original standing tree (through the first tag attached on it) to each log delivered to the sawmill.

The whole system proved effective in assessing the quality of timber at roadside. The optical sensors (not installed in the prototype) could identify decay spots and would warn the operator to recalculate the cutting instructions, which were based on the shape of the standing tree. From the point of view of a CSF application of this data, the system provides a further source of information which, when fully integrated with other sensor data, adds to the tool kit available for CSF planning and operations. Currently, only the logs with sufficient market value reach the sawmill and can be further analyzed with industrial sensors. However, the presence of 


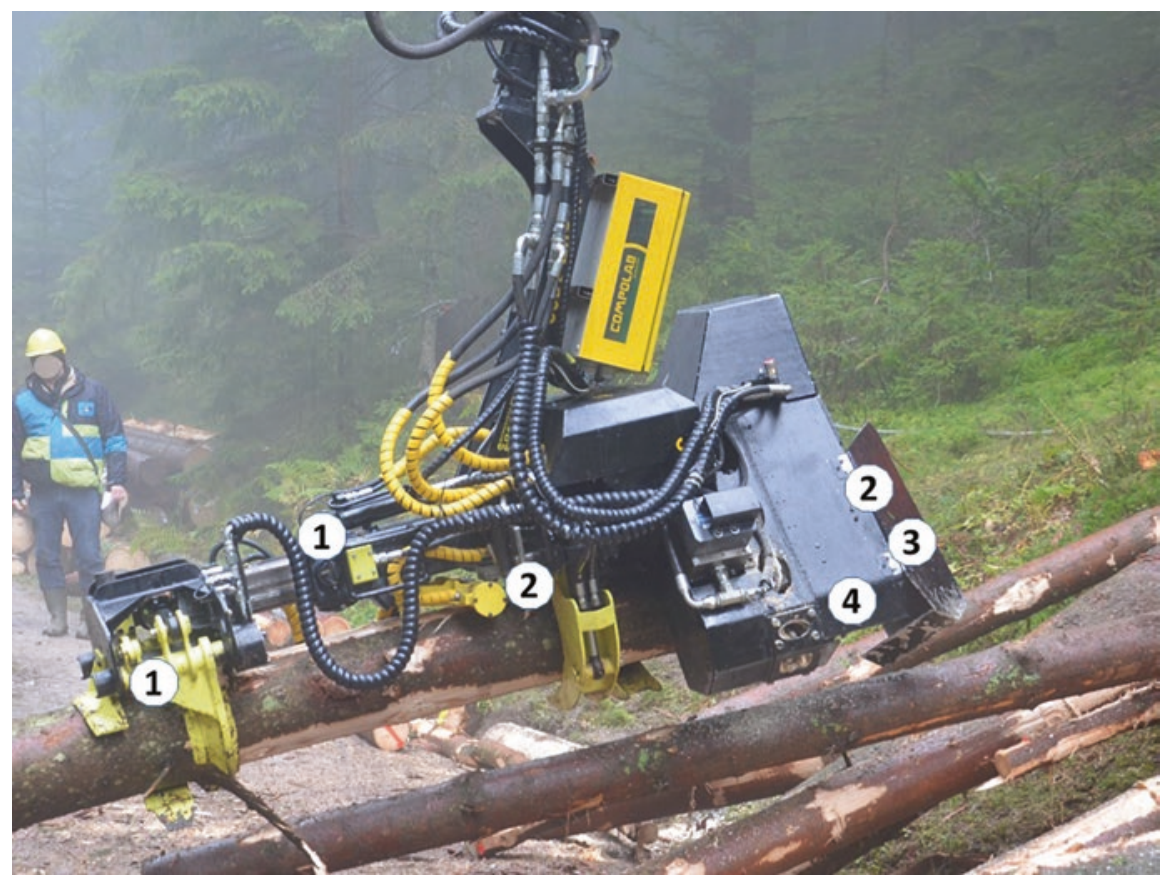

Fig. 9.13 Prototype of intelligent processor head equipped with sensors for timber quality assessment and tracking of logs

sensors on the processor head would provide data of lower quality (due to the work conditions), but as this is data from all the trees and logs produced in the stand, it is thus more representative of the general health of the trees. Once a track and trace system are fully integrated within the timber supply chain, it is possible to relate the information regarding each standing tree (and the logs produced from it) with the analysis performed in the sawmill. If the same trees were included in a network of sensors, the historical data collected by microcontrollers up to the tree felling could be related and integrated with all the information provided by all the sensors installed on the forest machines or the sawmilling facilities (Fig. 9.14).

The availability of an infrastructure for sensing, wireless transfer, and cloudelaboration of data developed for forest operations (and maintained by its revenues) is a clear opportunity for CSF. In fact, the network of sensors deployed for forest monitoring and management purposes could rely on this infrastructure for data transfer, storage, and elaboration. Furthermore, by accessing the databases of the virtual forest, it will be possible to integrate, validate, and broaden the data provided by the climate-smart sensors. The data used for operations planning and generated by machine sensors can be integrated with a unique, flexible system serving different long-, medium-, and short-term purposes, such as in situ forest monitoring (see Chap. 10 of this book: Tognetti et al. 2021), large-scale surveying of CSF indicators (see Chap. 11 of this book: Torresan et al. 2021), establishing a CSF network (see 


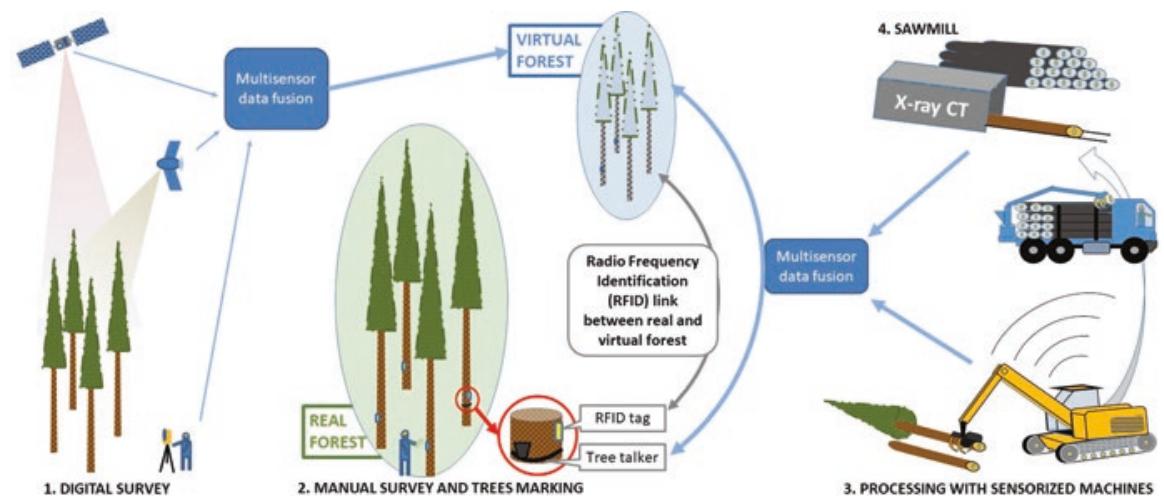

Fig. 9.14 Suitability of sensing technologies to timber characterization for industrial processing and for CSF applications

Chap. 5 of this book: Pretzsch et al. 2021), or implementing climate-smart silvicultural operations (see Chap. 8 of this book: Pach et al. 2021).

In turn, the data gathered for forest monitoring can be used for planning closeto-nature forestry operations. This improves the capacity to meet multiple goals, such as economic value, biodiversity, and forest resilience. Martín-Fernández and García-Abril Martín (2005) proved that if extensive and high-quality data is available, such planning can be performed at the level of individual trees by means of appropriate algorithms (iterative conditional mode), which otherwise could be applied only on small, intensively managed forest properties.

\subsection{Data Management in Timber Production and CSF}

As a final consideration, it is important to highlight how an essential aspect of the synergy between forest operations and CSF is the transfer, storage, elaboration, and harmonization of data collected by different sensors for different purposes (planning, production, invoicing, monitoring, forecast of health and growth dynamic, etc.). A further level of complexity is given by the perspective and capability of the different players of the supply chain, which produce and use data with different timing, purposes, technical tools, and frequency. This complexity is further increased by the additional target posed by CSF in the hypothesis of creating a unique system of data generation, elaboration, and exchange with a multipurpose vision.

Mortality and weakening control is accomplished by gathering and analyzing data with long-term field plots, where fixed low-cost networks of sensors are installed (see Chap. 10; Tognetti et al. 2021). Data can be effectively integrated with nondestructive sensors for timber quality, which identify timber quality parameters, such as defects, that can provide useful information regarding the health state of forests. In this sense, sensors installed on forest machines may bring a more valuable contribution than sawmill equipment in spite of the unavoidable 
lower precision. In fact, only quality timber is delivered to industrial users and analyzers. On the contrary, machine-based sensors are used to discriminate the logs among the supply chains of industrial timber, pulp, and biomass. Even if more detailed control will be dedicated to high-quality material, data must be generated for the selection of different classes, thus providing also valuable information regarding health parameters (rot, rings development, resistance wood, wood density, etc.).

A prerequisite for allowing applications and systems to communicate with each other in an agile and flexible way is the interoperability between systems and interfaces used. For this purpose, the Open Geospatial Consortium (OGC) and ISO created a web service interface standard for publishing, accessing, and visualizing spatiotemporal information (de la Beaujardiere 2006). In particular, the Sensor Web Enablement Initiative (SWE) promoted by the OGC proposed standards designed to collect data collected by sensors in a standardized way and augment the sensor data with the spatiotemporal dimension (Bröring et al. 2011). Thus, any machine control data or timber log data, mostly in the format of the Standard for Forest machine Data and Communication (StanForD), can be coupled with a spatial and temporal reference (Purfürst and Lindroos 2011). StandForD constitutes a de facto standard that covers all types of data communication present in forest machines and would probably require an upgrade, enabling it to exchange data provided by the new sensors that will soon be deployed on forest machines. By adopting the standards of SWE, it would also guarantee a standardized transmission, storage, and dissemination of the sensor data. This would be a fundamental step toward a wider use of the information produced, paving the way for a real integration of timber production and CSF.

\section{References}

Appelhanz S, Osburg V-S, Toporowski W, Schumann M (2015) Traceability system for capturing, processing and providing consumer-relevant information about wood products: system solution and its economic feasibility. J Clean Prod (forthcoming). https://doi.org/10.1016/j. jclepro.2015.02.034

Barth A, Holmgren J (2013) Stem taper estimates based on airborne laser scanning and cut-tolength harvester measurements for pre-harvest planning. Int J For Eng 24:161-169. https://doi. org/10.1080/14942119.2013.858911

Bettinger P, Boston K (2017) Forest planning heuristics-current recommendations and research opportunities for s-metaheuristics. Forests 8:476. https://doi.org/10.3390/f8120476

Björk A, Erlandsson M, Häkli J et al (2011) Monitoring environmental performance of the forestry supply chain using RFID. Comput Ind 62:830-841. https://doi.org/10.1016/j. compind.2011.08.001

Blagojević B, Jonsson R, Björheden R et al (2019) Multi-criteria decision analysis (MCDA) in Forest operations-an Introductional review. Šumarski fakultet Sveučilišta u Zagrebu

Bont L, Heinimann HR (2012) Optimum geometric layout of a single cable road. Eur J For Res 131:1439-1448. https://doi.org/10.1007/s10342-012-0612-y

Bosela M, Merganičová K, Torresan C, et al (2021) Modelling future growth of mountain forests under changing environments. In: Managing Forest Ecosystems, Vol. 40, Tognetti R, 
Smith M, Panzacchi P (Eds) Climate-Smart Forestry in Mountain Regions. Springer Nature, Switzerland, AG

Bowditch E, Santopuoli G, Binder F et al (2020) What is climate-smart forestry? A definition from a multinational collaborative process focused on mountain regions of Europe. Ecosyst Serv 43:101113. https://doi.org/10.1016/j.ecoser.2020.101113

Briggs DG, Thienel G, Turnblom EC, et al (2008) Influence of thinning on acoustic velocity of douglas-fir trees in Western Washington and Western Oregon. Symp A Q J Mod Foreign Lit

Bröring A, Echterhoff J, Jirka S et al (2011) New generation sensor web enablement. Sensors 11:2652-2699. https://doi.org/10.3390/s110302652

Cambi M, Certini G, Neri F, Marchi E (2015) The impact of heavy traffic on forest soils: a review. For Ecol Manag 338:124-138. https://doi.org/10.1016/j.foreco.2014.11.022

Cocozza C, Lasserre B, Giovannelli A et al (2009) Low temperature induces different cold sensitivity in two poplar clones (Populusxcanadensis Mönch "I-214" and P. deltoides Marsh. 'Dvina'). J Exp Bot 60:3655-3664. https://doi.org/10.1093/jxb/erp212

Cocozza C, Giovannelli A, Lasserre B et al (2012) A novel mathematical procedure to interpret the stem radius variation in olive trees. Agric For Meteorol 161:80-93. https://doi.org/10.1016/j. agrformet.2012.03.016

Cocozza C, Tognetti R, Giovannelli A (2018) High-resolution analytical approach to describe the sensitivity of tree-environment dependences through stem radial variation. Forests 9:134. https://doi.org/10.3390/f9030134

Cruz-García R, Balzano A, Čufar K et al (2019) Combining dendrometer series and Xylogenesis imagery - DevX, a simple visualization tool to explore plant secondary growth phenology. Front For Glob Chang 2:1-13. https://doi.org/10.3389/ffgc.2019.00060

de la Beaujardiere J (2006) OpenGIS® web map server implementation specification

Drew DM, Downes GM (2009) The use of precision dendrometers in research on daily stem size and wood property variation: a review. Dendrochronologia 27:159-172. https://doi. org/10.1016/j.dendro.2009.06.008

Đuka A, Grigolato S, Papa I et al (2017) Assessment of timber extraction distance and skid road network in steep karst terrain. IForest 10:886-894. https://doi.org/10.3832/ifor2471-010

Eriksson M, Lindroos O (2014) Productivity of harvesters and forwarders in CTL operations in northern Sweden based on large follow-up datasets. Int J For Eng 25:179-200. https://doi.org/1 0.1080/14942119.2014.974309

Favero A, Daigneault A, Sohngen B (2020) Forests: carbon sequestration, biomass energy, or both? Sci Adv 6:1-14. https://doi.org/10.1126/sciadv.aay6792

Gergel T, Bucha T, Gejdoš M, Vyhnáliková Z (2019) Computed tomography log scanning high technology for forestry and forest based industry. Cent Eur For J 65:51-59. https://doi. org/10.2478/forj-2019-0003

Giovannelli A, Deslauriers A, Fragnelli G et al (2007) Evaluation of drought response of two poplar clones (Populus x canadensis Mönch "I-214" and P. deltoides Marsh. 'Dvina') through high resolution analysis of stem growth. J Exp Bot 58:2673-2683. https://doi.org/10.1093/ jxb/erm117

Gjerdrum P, Bernabei M (2007) Three-dimensional model for size and location of resin pockets in stems of Norway spruce. Holz als Roh und Werkst 65:201-208. https://doi.org/10.1007/ s00107-006-0158-0

Görgens EB, Mund JP, Cremer T et al (2020) Automated operational logging plan considering multi-criteria optimization. Comput Electron Agric 170:105253. https://doi.org/10.1016/j. compag.2020.105253

Holopainen M, Vastaranta M, Hyyppä J (2014) Outlook for the next generation's precision forestry in Finland. Forests 5:1682-1694. https://doi.org/10.3390/f5071682

Holtsmark B (2012) Harvesting in boreal forests and the biofuel carbon debt. Clim Chang 112:415-428. https://doi.org/10.1007/s10584-011-0222-6

Innes JL, Cook ER (1989) Tree-ring analysis as an aid to evaluating the effects of pollution on tree growth. Can J For Res 19:1174-1189. https://doi.org/10.1139/x89-177 
Jones TG, Downes GM, Watt MS et al (2013) Effect of stem bending and soil moisture on the incidence of resin pockets in radiata pine. NZ J For Sci 43:1-14. https://doi.org/10.1186/11795395-43-10

Kaakkurivaara N (2019) Possibilities of using barcode and RFID technology in Thai timber industry. Maejo Int J Sci Technol 13:29-41

Kaakkurivaara T, Kaakkurivaara N (2019) Comparison of radio frequency identification tag housings in a tropical forestry work environment. Aust For 00:1-8. https://doi.org/10.1080/0004915 8.2019.1678797

Kauppi P, Hanewinkerl M, Lundmark T, et al (2018) Climate smart forestry in Europe. European Forest Institute

Keenan RJ (2015) Climate change impacts and adaptation in forest management: a review. Ann For Sci 72:145-167. https://doi.org/10.1007/s13595-014-0446-5

Keleş S, Baskent EZ (2011) Joint production of timber and water: a case study. Water Policy 13:535-546. https://doi.org/10.2166/wp.2011.125

Kidombo SD, Dean TJ (2018) Growth of tree diameter and stem taper as affected by reduced leaf area on selected branch whorls. Can J For Res 48:317-323. https://doi.org/10.1139/ cjfr-2017-0279

Kimbar R (2011) Wady drewna (in Polish). Osie

Korten S, Kaul C (2008) Application of RFID (radio frequency identification) in the timber supply chain. Croat J For Eng 29:85-94

Laurila J, Lauhanen R (2012) Weight and volume of small-sized whole trees at different phases of the supply chain. Scand J For Res 27:46-55. https://doi.org/10.1080/02827581.2011.629621

Lindberg E, Holmgren J (2017) Individual tree crown methods for 3D data from remote sensing. Curr For Rep 3:19-31. https://doi.org/10.1007/s40725-017-0051-6

Lindroos O, Ringdahl O, Pedro LH et al (2015) Estimating the position of the harvester head - a key step towards the precision forestry of the future? Croat J For Eng 36:147-164

Łszczyńska K, Malik I, Wistuba M, Krąpiec M (2019) Assessment of landslide hazard from treering eccentricity and from compression wood - a comparison. Geol Q 63:296-301. https://doi. org/10.7306/gq. 1472

Lu K, Bi H, Watt D et al (2018) Reconstructing the size of individual trees using log data from cut-to-length harvesters in Pinus radiata plantations: a case study in NSW, Australia. J For Res 29:13-33. https://doi.org/10.1007/s11676-017-0517-1

Ma T, Inagaki T, Tsuchikawa S (2017) High spatial resolution and non-destructive evaluation of wood density and microfibril angle by NIR hyperspectral imaging. NIR News 28:7-12. https:// doi.org/10.1177/0960336017703259

Marchi E, Chung W, Visser R et al (2018) Sustainable Forest operations (SFO): a new paradigm in a changing world and climate. Sci Total Environ 634:1385-1397. https://doi.org/10.1016/j. scitotenv.2018.04.084

Martín-Fernández S, García-Abril A (2005) Optimisation of spatial allocation of forestry activities within a forest stand. Comput Electron Agric 49:159-174. https://doi.org/10.1016/j. compag.2005.02.012

Matasci G, Hermosilla T, Wulder MA et al (2018) Large-area mapping of Canadian boreal forest cover, height, biomass and other structural attributes using Landsat composites and lidar plots. Remote Sens Environ 209:90-106. https://doi.org/10.1016/j.rse.2017.12.020

Matasov V, Marchesini LB, Yaroslavtsev A et al (2020) IoT monitoring of urban tree ecosystem services: possibilities and challenges. Forests 11:775. https://doi.org/10.3390/F11070775

Matthies BD, Jacobsen JB, Knoke T et al (2019) Utilising portfolio theory in environmental research - new perspectives and considerations. J Environ Manag 231:926-939

Mattila U, Tokola T (2019) Terrain mobility estimation using TWI and airborne gamma-ray data. J Environ Manag 232:531-536. https://doi.org/10.1016/J.JENVMAN.2018.11.081

Mavridou E, Vrochidou E, Papakostas GA et al (2019) Machine vision systems in precision agriculture for crop farming. J Imaging 5. https://doi.org/10.3390/jimaging5120089 
Meder R, Meglen R (2012) Near infrared spectroscopic and hyperspectral imaging of compression wood in Pinus radiata D. Don J Near Infrared Spectrosc 20:583. https://doi.org/10.1255/ jnirs.1001

Mederski PS, Bembenek M, Karaszewski Z et al (2018) Investigation of log length accuracy and harvester efficiency in processing of oak trees. Croat J For Eng 39:173-181

Mengesha T, Hawkins M, Nieuwenhuis M (2015) Validation of terrestrial laser scanning data using conventional forest inventory methods. Eur J For Res 134:211-222

Mina M, Martin-Benito D, Bugmann H, Cailleret M (2016) Forward modeling of tree-ring width improves simulation of forest growth responses to drought. Agric For Meteorol 221:13-33. https://doi.org/10.1016/j.agrformet.2016.02.005

Mitchell HB (2012) Data fusion: concept and ideas. pp. 347, Springer, ISBN 978-3-642-27222-6

Möller B, Wikander J, Hellgren M (2011) A field-tested log traceability system. For Prod J 61:466-472. https://doi.org/10.13073/0015-7473-61.6.466

Murphy PNC, Ogilvie J, Castonguay M et al (2008) Improving forest operations planning through high-resolution flow-channel and wet-areas mapping. For Chron 84:568-574. https://doi. org/10.5558/tfc84568-4

Murphy G, Clark JA, Pilkerton S (2012) Current and potential tagging and tracking Systems for Logs Harvested from Pacific Northwest Forests. West J Appl For 27:84-91. https://doi. org/10.5849/wjaf.11-027

Niemi MT, Vastaranta M, Vauhkonen J et al (2017) Airborne LiDAR-derived elevation data in terrain trafficability mapping. Scand J For Res 32:762-773. https://doi.org/10.1080/0282758 1.2017.1296181

Noordermeer L, Bollandsås OM, Ørka HO et al (2019) Comparing the accuracies of forest attributes predicted from airborne laser scanning and digital aerial photogrammetry in operational forest inventories. Remote Sens Environ 226:26-37. https://doi.org/10.1016/j.rse.2019.03.027

Olivera A, Visser R (2016) Development of forest-yield maps generated from Global Navigation Satellite System (GNSS)-enabled harvester StanForD files: preliminary concepts. NZ J For Sci 46:1-10. https://doi.org/10.1186/s40490-016-0059-x

Ovando P, Speich M (2020) Optimal harvesting decision paths when timber and water have an economic value in uneven forests. Forests 11:1-26. https://doi.org/10.3390/F11090903

Pach M, Bielak K, Bončina A, et al (2021) Climate-smart silviculture in mountain regions. In: Managing Forest Ecosystems, Vol. 40, Tognetti R, Smith M, Panzacchi P (Eds) Climate-Smart Forestry in Mountain Regions. Springer Nature, Switzerland, AG

Palander TS, Eronen JP, Peltoniemi NP et al (2019) Improving a stem-damage monitoring system for a single-grip harvester using a logistic regression model in image processing. Biosyst Eng 180:36-49. https://doi.org/10.1016/j.biosystemseng.2019.01.011

Paradis N, Auty D, Carter P, Achim A (2013) Using a standing-tree acoustic tool to identify forest stands for the production of mechanically-graded lumber. Sensors (Switzerland) 13:3394-3408. https://doi.org/10.3390/s130303394

Peuhkurinen J (2011) Estimating tree size distributions and timber assortment recoveries for wood procurement planning using airborne laser scanning. University of Eastern Finland

Picchi G (2020) Marking standing trees with RFID tags. Forests 11:1-13. https://doi.org/10.3390/ f11020150

Picchi G, Kühmaier M, Marques JDD (2015) Survival test of RFID UHF tags in timber harvesting operations. Croat J For Eng 36:165-174

Pichler G, Poveda Lopez JAA, Picchi G et al (2017) Comparison of remote sensing based RFID and standard tree marking for timber harvesting. Comput Electron Agric 140:214-226. https:// doi.org/10.1016/j.compag.2017.05.030

Piragnolo M, Grigolato S, Pirotti F (2019) Planning harvesting operations in forest environment: remote sensing for decision support. ISPRS Ann Photogramm Remote Sens Spat Inf Sci IV-3(W1):33-40. https://doi.org/10.5194/isprs-annals-IV-3-W1-33-2019

Pirotti F, Grigolato S, Lingua E et al (2012) Laser scanner applications in Forest and environmental sciences. Ital J Remote Sens 44:109-123. https://doi.org/10.5721/ItJRS20124419 
Puliti S, Hauglin M, Breidenbach J et al (2020) Modelling above-ground biomass stock over Norway using national forest inventory data with ArcticDEM and Sentinel-2 data. Remote Sens Environ 236:111501. https://doi.org/10.1016/j.rse.2019.111501

Pretzsch H, del Río M, Giammarchi F, Uhl E, Tognetti R (2021) Changes of tree and stand growth. Review and implications. In: Managing Forest Ecosystems, Vol. 40, Tognetti R, Smith M, Panzacchi P (Eds) Climate-Smart Forestry in Mountain Regions. Springer Nature, Switzerland, AG

Purfürst T, Lindroos O (2011) The correlation between long-term productivity and short-term performance ratings of harvester operators. Croat J For Eng 32:509-519

Raatevaara A, Korpunen H, Mäkinen H, Uusitalo J (2020) Log end face image and stem tapering indicate maximum bow height on Norway spruce bottom logs. Eur J For Res 139:1079-1090. https://doi.org/10.1007/s10342-020-01309-0

Rais A, Ursella E, Vicario E, Giudiceandrea F (2017) The use of the first industrial X-ray CT scanner increases the lumber recovery value: case study on visually strength-graded Douglas-fir timber. Ann For Sci 74:1-9. https://doi.org/10.1007/s13595-017-0630-5

Raschi A, Tognetti R, Ridder H-W, Beres C (1995) Water in the stems of sessile oak (Quercus petraea) assessed by computer tomography with concurrent measurements of sap velocity and ultrasound emission. Plant Cell Environ 18:545-554. https://doi.org/10.1111/j.13653040.1995.tb00554.x

Rossit DA, Olivera A, Viana Céspedes V, Broz D (2019) A big data approach to forestry harvesting productivity. Comput Electron Agric 161:29-52. https://doi.org/10.1016/j. compag.2019.02.029

Rossmann J, Schluse M, Schlette C (2009) The virtual forest: robotics and simulation technology as the basis for new approaches to the biological and the technical production in the forest. In: WMSCI 2009 - the 13th world multi-conference on systemics, cybernetics and informatics, jointly with the 15th international conference on information systems analysis and synthesis, ISAS 2009 - Proceedings, pp 33-38

Russo D, Marziliano PA, Macrì G et al (2020) Tree growth and wood quality in pure vs. mixedspecies stands of european beech and Calabrian pine in Mediterranean mountain forests. Forests 11:6. https://doi.org/10.3390/F11010006

Salmivaara A, Miettinen M, Finér L et al (2018) Wheel rut measurements by forest machinemounted LiDAR sensors - accuracy and potential for operational applications? Int J For Eng 00:1-12. https://doi.org/10.1080/14942119.2018.1419677

Sandak A, Sandak J, Böhm K, Hinterstoisser B (2016a) Near infrared spectroscopy as a tool for in - field determination of $\log /$ biomass quality index in mountain forests. J Near Infrared Spectrosc 24:587-594. https://doi.org/10.1255/jnirs.1231

Sandak J, Sandak A, Meder R (2016b) Assessing trees, wood and derived products with near infrared spectroscopy: hints and tips. J Near Infrared Spectrosc 24:485-505. https://doi. org/10.1255/jnirs. 1255

Sandak A, Sandak J, Waliszewska B et al (2017) Selection of optimal conversion path for willow biomass assisted by near infrared spectroscopy. IForest 10:506-514. https://doi.org/10.3832/ ifor1987-010

Sandak J, Sandak A, Marrazza S, Picchi G (2019) Development of a sensorized timber processor head prototype - part 1: sensors description and hardware integration. Croat J For Eng 40:25-37

Sandak J, Sandak A, Zitek A et al (2020) Development of low-cost portable spectrometers for detection of wood defects. Sensors (Switzerland) 20. https://doi.org/10.3390/s20020545

Schajer GS, Orhan FB (2005) Microwave non-destructive testing of wood and similar orthotropic materials. Subsurf Sens Technol Appl 6:293-313. https://doi.org/10.1007/ s11220-005-0014-z

Schneider R (2018) Understanding the factors influencing stem form with modelling tools. Springer, Cham, pp 295-316

Schraml R, Charwat-Pessler J, Petutschnigg A, Uhl A (2015) Towards the applicability of biometric wood log traceability using digital log end images. Comput Electron Agric 119:112-122. https://doi.org/10.1016/j.compag.2015.10.003 
Schraml R, Entacher K, Petutschnigg A et al (2020) Matching score models for hyperspectral range analysis to improve wood log traceability by fingerprint methods. Mathematics 8 . https:// doi.org/10.3390/MATH8071071

Searchinger TD, Beringer T, Holtsmark B et al (2018) Europe's renewable energy directive poised to harm global forests. Nat Commun 9:10-13. https://doi.org/10.1038/ s41467-018-06175-4

Seifert T, Breibeck J, Seifert S, Biber P (2010) Resin pocket occurrence in Norway spruce depending on tree and climate variables. For Ecol Manag 260:302-312. https://doi.org/10.1016/j. foreco.2010.03.024

Shenga PA, Bomark P, Broman O (2015) External log scanning for optimizing primary breakdown of tropical hardwood species. In: 22nd international wood machining seminar. Quebec, Canada, pp 65-72

Sheppard JP, Chamberlain J, Agúndez D et al (2020) Sustainable Forest management beyond the timber-oriented status quo: transitioning to co-production of timber and non-wood forest products - a global perspective. Curr For Rep 6:26-40. https://doi.org/10.1007/ s40725-019-00107-1

Siekański P, Magda K, Malowany K et al (2019) On-line laser triangulation scanner for wood logs surface geometry measurement. Sensors 19:1074. https://doi.org/10.3390/s19051074

Stängle SM, Brüchert F, Kretschmer U et al (2014) Clear wood content in standing trees predicted from branch scar measurements with terrestrial LiDAR and verified with X-ray computed tomography. Can J For Res 44:145-153

Stängle SM, Brüchert F, Heikkila A et al (2015) Potentially increased sawmill yield from hardwoods using X-ray computed tomography for knot detection. Ann For Sci 72:57-65. https:// doi.org/10.1007/s13595-014-0385-1

Sterenczak K, Moskalik T (2015) Use of LIDAR-based digital terrain model and single tree segmentation data for optimal forest skid trail network. iForest Biogeosci For 8:661-667. https:// doi.org/10.3832/ifor1355-007

Subah S, Dermninder S, Sanjeev C (2017) An interactive computer vision system for tree ring analysis. Curr Sci 112:1262-1265

Sun SJ, Lei S, Jia HS et al (2020) Tree-ring analysis reveals density-dependent vulnerability to drought in planted Mongolian pines. Forests 11:1-17. https://doi.org/10.3390/f11010098

Taube P, Orłowski KA, Chuchała D, Sandak J (2020) The effect of log sorting strategy on the forecasted lumber value after sawing pine wood. Acta Fac Xylologiae Zvolen 62:89-102. https:// doi.org/10.17423/afx.2020.62.1.08

Thumm A, Riddell M, Nanayakkara B et al (2010) Near infrared hyperspectral imaging applied to mapping chemical composition in wood samples. J Near Infrared Spectrosc 18:507-515. https://doi.org/10.1255/jnirs.909

Tognetti R, Raschi A, Beres C et al (1996) Comparison of sap flow, cavitation and water status of Quercus petraea and Quercus cerris trees with special reference to computer tomography. Plant Cell Environ 19:928-938. https://doi.org/10.1111/j.1365-3040.1996.tb00457.x

Tognetti R, Giovannelli A, Lavini A et al (2009) Assessing environmental controls over conductances through the soil-plant-atmosphere continuum in an experimental olive tree plantation of southern Italy. Agric For Meteorol 149:1229-1243. https://doi.org/10.1016/j. agrformet.2009.02.008

Tognetti R, Valentini R, Belelli Marchesini L, Gianelle D, Panzacchi P, Marshall JD (2021) Continuous monitoring of tree responses to climate change for smart forestry - a cybernetic web of trees. In: Managing Forest Ecosystems, Vol. 40, Tognetti R, Smith M, Panzacchi P (Eds) Climate-Smart Forestry in Mountain Regions. Springer Nature, Switzerland, AG

Torresan C, Luyssaert S, Filippa G, Imangholiloo M, Gaulton R (2021) Remote sensing technologies for assessing climate-smart criteria in mountain forests. In: Managing Forest Ecosystems, Vol. 40, Tognetti R, Smith M, Panzacchi P (Eds) Climate-Smart Forestry in Mountain Regions. Springer Nature, Switzerland, AG 
Tzoulis IK, Andreopoulou ZS, Voulgaridis E (2014) Wood tracking information systems to confront illegal logging. J Agric Inform 5:9-17

Uner B, Oyar O, Var AA, Altnta OL (2009) Effect of thinning on density of Pinus nigra tree using X-ray computed tomography. J Environ Biol 30:359-362

Valbuena R, Mauro F, Rodríguez-Solano R, Manzanera JA (2012) Partial least squares for discriminating variance components in global navigation satellite systems accuracy obtained under scots pine canopies. For Sci 58:139-153. https://doi.org/10.5849/forsci.10-025

Van den Bulcke J, Wernersson ELG, Dierick M et al (2014) 3D tree-ring analysis using helical X-ray tomography. Dendrochronologia 32:39-46. https://doi.org/10.1016/j.dendro.2013.07.001

Venanzi R, Picchio R, Grigolato S, Latterini F (2019) Soil and forest regeneration after different extraction methods in coppice forests. For Ecol Manag 454. https://doi.org/10.1016/j. foreco.2019.117666

Walker XJ, Mack MC, Johnstone JF (2017) Predicting ecosystem resilience to fire from tree ring analysis in black spruce forests. Ecosystems 20:1137-1150. https://doi.org/10.1007/ s10021-016-0097-5

Walsh D, Strandgard M, Carter P (2014a) Evaluation of the Hitman PH330 acoustic assessment system for harvesters. Scand J For Res 29:593-602. https://doi.org/10.1080/0282758 1.2014.953198

Walsh D, Strandgard M, Carter P (2014b) Evaluation of the Hitman PH330 acoustic assessment system for harvesters. Scand J For Res 29:593-602. https://doi.org/10.1080/0282758 1.2014 .953198

White JC, Coops NC, Wulder MA et al (2016) Remote sensing technologies for enhancing forest inventories: a review. Can J Remote Sens 42:619-641. https://doi.org/10.1080/0703899 2.2016.1207484

Woollons R, Manley B, Park J (2008) Factors influencing the formation of resin pockets in Pruned radiata pine butt logs from New Zealand. NZ J For Sci 38:323-334

Yousefpour R, Augustynczik ALD, Reyer CPO et al (2018) Realizing mitigation efficiency of European commercial forests by climate smart forestry. Sci Rep 8:1-11. https://doi. org/10.1038/s41598-017-18778-w

Zeller L, Ammer C, Annighöfer P et al (2017) Tree ring wood density of Scots pine and European beech lower in mixed-species stands compared with monocultures. For Ecol Manag 400:363-374. https://doi.org/10.1016/j.foreco.2017.06.018

Zobel BJ, Jett JB (1995) The importance of wood density (specific gravity) and its component parts. In: Genetics of wood production. Springer, Berlin/Heidelberg

Zweifel R, Steppe K, Sterck FJ (2007) Stomatal regulation by microclimate and tree water relations: interpreting ecophysiological field data with a hydraulic plant model. J Exp Bot 58:2113-2131. https://doi.org/10.1093/jxb/erm050

Open Access This chapter is licensed under the terms of the Creative Commons Attribution 4.0 International License (http://creativecommons.org/licenses/by/4.0/), which permits use, sharing, adaptation, distribution and reproduction in any medium or format, as long as you give appropriate credit to the original author(s) and the source, provide a link to the Creative Commons license and indicate if changes were made.

The images or other third party material in this chapter are included in the chapter's Creative Commons license, unless indicated otherwise in a credit line to the material. If material is not included in the chapter's Creative Commons license and your intended use is not permitted by statutory regulation or exceeds the permitted use, you will need to obtain permission directly from the copyright holder.

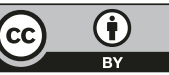

